\title{
EVALUATION OF AIR CLEANING SYSTEMS FOR FFTF CONTAINMENT MARGINS
}

\section{Hanford Engineering Development Laboratory}

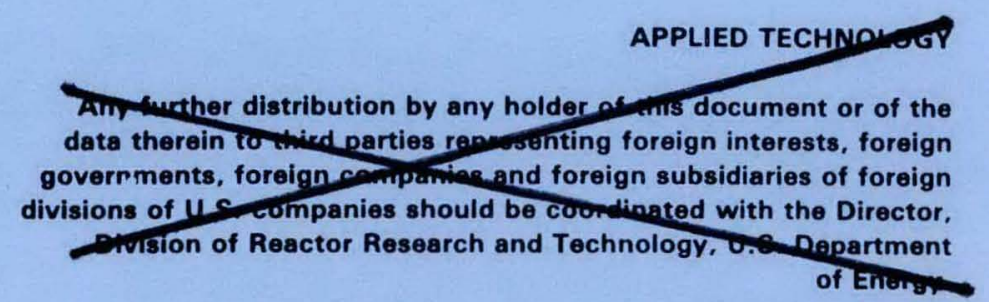

P.O. Box 1970 Richland, WA 99352

A Subsidiary of Westinghouse Electric Corporation

Prepared for the U.S. Department of Energy under Contract No. DE-AC1476FF02170. 


\section{NOTICE}

This report was prepared as an account of work sponsored by the United States Government. Neither the United States nor the U.S. Department of Energy (DOE), nor any of its employes, nor any of its contractors, subcontractors or their employes, makes any warranty, expressed or implied, or assumes any legal liability or responsibility for any third party's use or the results of such use of any information, apparatus, product or process disclosed in this report, or represents that its use by such third party would not infringe privately owned rights.

Printed in the United States of America

Available from

DOE Technical Information Center

P.O. Box 62

Oak Ridge, TN 37830

NTIS price codes

Printed Copy: A04

Microfiche copy: A01 


\section{EVALUATION OF AIR CLEANING SYSTEMS FOR FFTF CONTAINMENT MARGINS}

\section{Hanford Engineering Development Laboratory}

A.K. Postma
R.K. Hilliard

August 1980

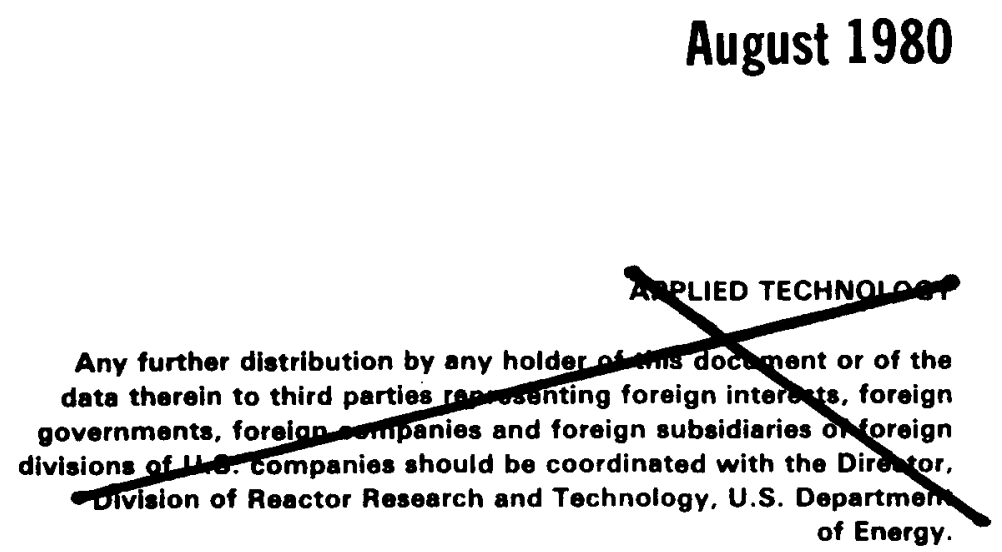

$05 / 22 / 2013$

Approved for Public Release;

Further Dissemination Unimited

A. D. Mardal
HANFORD ENGINEERING DEVELOPMENT LABORATORY Operated by Westinghouse Hanford Company

P.O. Box 1970 Richland, WA 99352

A Subsidiary of Westinghouse Electric Corporation Prepared for the U.S. Department of Energy under Contract No. DE-AC1476FF02170. 
HEDL-TME 79-79

UC $-79 i, p$

EVALUATION OF AIR CLEANING

SYSTEMS FOR FFTF CONTAINMENT MARGINS

A. K. Postma

R. K. Hilliard

\begin{abstract}
Alternative air cleaning concepts were evaluated for possible application to FFTF containment margins. For evaluation purposes, it was assumed that the air cleaning system must process $3.07 \mathrm{~m}^{3} / \mathrm{s}$ (6500 ACFM) of gas containing sodium compound aerosols (mainly $\mathrm{NaOH})$ at temperatures up to $407^{\circ} \mathrm{C}\left(700^{\circ} \mathrm{F}\right)$ and pressures up to $0.184 \mathrm{MPa}(26.4 \mathrm{psia})$ and accommodate $5450 \mathrm{~kg}(12,000 \mathrm{lb})$ of aerosol material. Three systems designed for $90 \%$ efficient removal (a venturi scrubber, a submerged gravel scrubber and a spray scrubber) were compared. The submerged gravel scrubber and the venturi scrubber were rated as prime candidates. Four systems designed for $99 \%$ removal efficiency (the two "optimum scrubbers" chosen for $90 \%$ removal efficiency fitted with fibrous elements, a sand and gravel filter and a HEPA filter bank) were compared. The two scrubbers were again rated as prime candidates. Both the sand and gravel filter and the HEPA filter bank were found to be excessively large and costly. Considerable experience supports the use of the "optimum" scrubber systems and it is concluded that their use is technically feasible for the FFTF containment margins application.
\end{abstract}


This work was performed under the sponsorship of the Safety and Physics Branch, Division of Reactor Research and Technology, U.S. Department of Energy. The authors wish to acknowledge the significant advice and guidance by M.K. Mahaffey, H.C. Martin, J.D. McCormack, L.D. Muhlestein, R.D. Peak and D.D. Stepnewski of HEDL and K.R. Absher and G.D. Bouchey of the FFTF Project Office. 


\section{CONTENTS}

$\underline{\text { Page }}$

Abstract

$i \mathrm{i}$

Ack now ledgments

iv

Figures

vii

Tables

viii

I. SUMMARY AND CONCLUSIONS 1

A. SUMMARY 1

B. CONCLUSIONS 1

II . INTRODUCTION 3

III. AIR CLEANING REQUIREMENTS

A. BASIS 5

B. THERMAL CONDITIONS 5

C. CHEMICAL FORMS OF GASES AND AEROSOLS 7

D. AEROSOL PARTICLE SIZE DISTRIBUTION 8

E. GAS FLOW RATE 9

F. AEROSOL MASS COLLECTION 9

G. REQUIRED REMOVAL EFFICIENCY 10

H. COMPARISON OF DESIGN PARAMETERS 10

IV. PRELIMINARY SCREENING OF AIR CLEANING CONCEPTS

V. CRITERIA FOR RANK ING ALTERNATIVE SYSTEMS 15

VI . EVALUATION RESULTS 21

A. DESCRIPTION OF SYSTEMS DESIGNED FOR 90\% EFFICIENCY 21

1. Venturi Scrubber - System LE-1 21

2. Submerged Gravel Scrubber - System LE-2 23

3. Spray Chamber - System LE-3 27 


\section{CONTENTS (Cont'd)}

B. DESCRIPTION OF SYSTEMS DESIGNED FOR $99 \%$ EFFICIENCY

1. Venturi Scrubber with Fibrous Backup System HE-1

2. Submerged Gravel Scrubber with Fibrous

Backup - System HE-2

3. Sand and Gravel Bed - System HE-3

4. HEPA Filters - System HE-4

C. COMPARISON OF ALTERNATIVE SYSTEMS

1. Ranking of $90 \%$ Efficient Candidates

2. Ranking of $99 \%$ Efficient Candidates

D. FEASIBILITY OF ASSESSMENT OF AIR CLEANING SYSTEMS FOR FFTF CONTAINMENT MARGIN APPLICATIONS

VII. REFERENCES

APPENDIX A NUMERICAL RANKING OF 90\% EFFICIENT SYSTEMS

A-1

APPENDIX B NUMERICAL RANK ING OF 99\% EFFICIENT SYSTEMS

B-1 


\section{FIGURES}

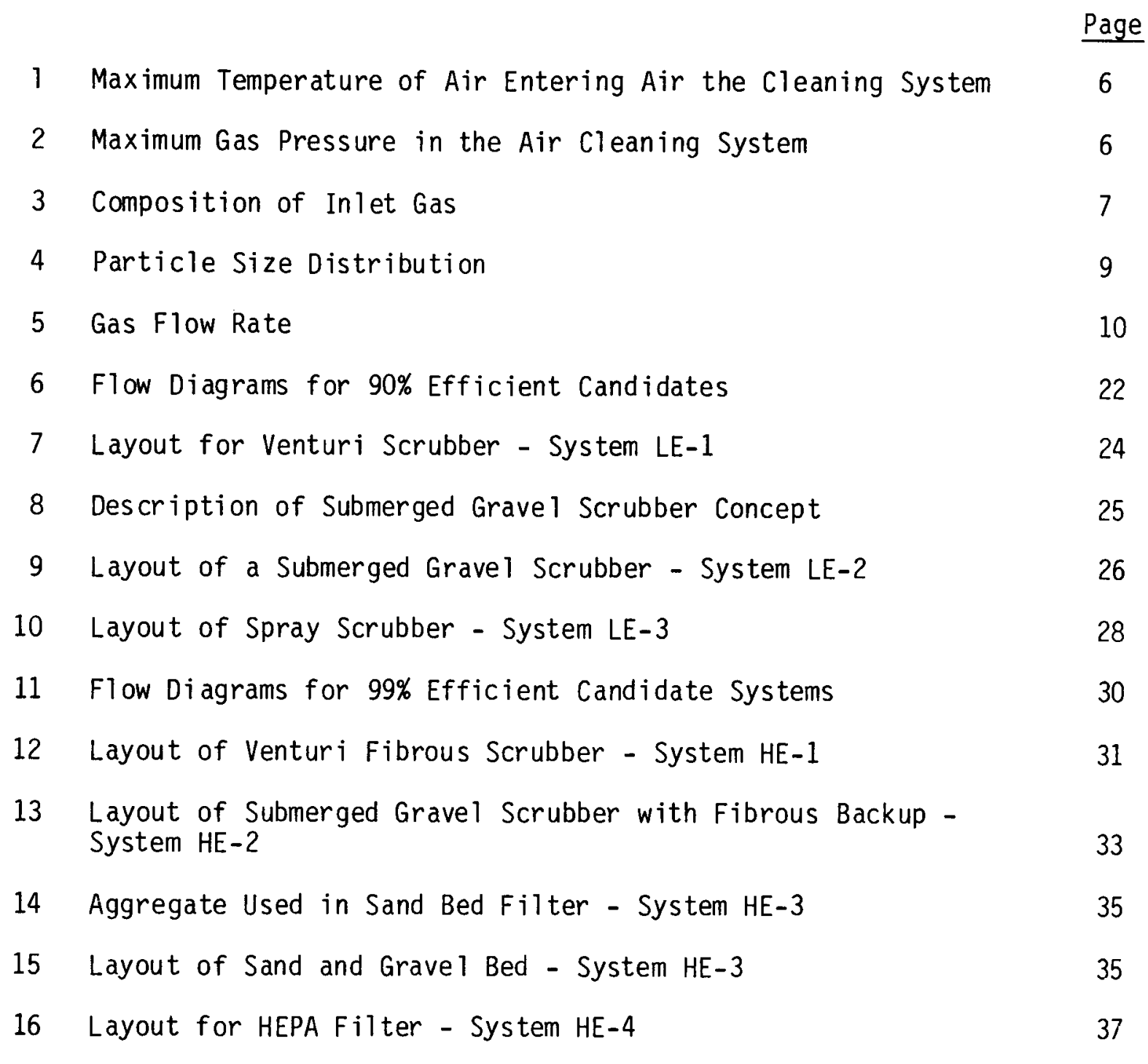


1 Comparison of Air Cleaning System Requirements

2 Preliminary Screening of Air Cleaning System Concepts

3 Air Cleaning Evaluation Criteria Groups

4 Evaluation Criteria for Air Cleaning Systems

5 Rating $\mathrm{Factors}$ for Air Cleaning Systems

6 Criteria with Mandatory Acceptable Ratings

7 Parameters for Venturi Scrubber - System LE-1

8 Parameters for Submerged Gravel Scrubber - System LE-2

9 Parameters for Spray Scrubber - System LE-3

10 Parameters for Venturi/Fibrous Scrubber - System HE-1

11 Parameters for Submerged Gravel Bed/Fibrous Scrubber System HE-2

12 Parameters for Sand and Gravel Bed - System HE-3 36

13 Parameters for HEPA Fil ters - System HE-4

14 Numerical Ratings of 90\% Efficient Systems

15 Numerical Ratings of $99 \%$ Efficient Systems

B-1 System Reliability Ratings

B-2 System Design Ratings 
EVALUATION OF AIR CLEANING SYSTEMS FOR

FFTF CONTAINMENT MARGINS (WAKVAA)

I. SUMMARY AND CONCLUSIONS

\section{A. SUMMARY}

An evaluation of alternative air cleaning systems was made to identify the most promising candidates for application to Fast Flux Test Facility (FFTF) containment margins. Seven candidate systems were selected for detailed comparison. The three systems capable of 90\% aerosol removal efficiency were: 1) eductor venturi, 2) spray chamber scrubber and 3) submerged gravel bed. The four systems for $99 \%$ efficiency were: 1) eductor venturi/fibrous scrubber, 2) submerged gravel bed/fibrous scrubber, 3) sand and gravel bed and 4) HEPA filters.

A conceptual design was developed for each system to show size and major components, and to allow an approximate cost estimate. The systems within each efficiency class were then compared using a criteria list and candidate ratings were made. The rating process identified two prime candidates from each removal efficiency class. Final selection will be based on trade-off studies beyond the scope of this report.

\section{B. CONCLUSIONS}

Specific conclusions drawn from work completed are:

- For the $90 \%$ removal efficiency case, two scrubber systems (an eductor venturi and submerged gravel bed) were rated as prime candidates. The submerged gravel bed was superior to the eductor venturi in passivity and mechanical simplicity but it lacks an extensive use-history.

- For the $99 \%$ removal case, the eductor venturi and the submerged gravel bed scrubber systems were also prime candidates when upgraded by adding a packed bed back-up stage of polypropylene fibers. 
- A spray chamber scrubber designed for $90 \%$ efficiency is larger and more costly to construct and to operate than the prime candidates; therefore, it was eliminated from further consideration.

- The sand and gravel bed (the 99\% removal case) was found too 1 arge and costly to construct for use in the present application. The 1 arge aerosol mass load requires a sand bed with a planar area of more than 1 acre and a cost of tens of millions of dollars.

- A system using high efficiency particulate air (HEPA) filters, designed for the $99 \%$ removal case, was eliminated. The aerosol mass loading required a 1 arge number (9100) of filter units (0.61 $\mathrm{m} \times 0.61 \mathrm{~m} \times 0.3 \mathrm{~m}$ deep) enclosed in a pressure boundary, making this system too 1 arge and costly.

- Both prime candidates (the eductor venturi and the submerged grave 7 bed) would require a planar area of less than $150 \mathrm{~m}^{2}$ $\left(1600 \mathrm{ft}^{2}\right)$ and therefore, could be located adjacent to the containment vessel.

- A significant experience base exists for trapping sodium compound aerosols by aqueous scrubbers. The use of aqueous scrubbers is technically feasible for the FFTF containment margins application. 
II. INTRODUCTION

Although extensive analyses of hypothetical core disruptive accident (HCDA) events in the FFTF show that the heat transport system would remain intact and the fuel coolable, further safety margins available for a postulated reactor vessel melt-through were assessed ${ }^{(1)}$. In the assessment, it was assumed that the containment vessel would be vented to relieve overpressure and/or purged to prevent hydrogen buildup. Although the potential site boundary radiation exposures were within 10 CFR $100^{(2)}$ guideline values (even without the use of a filter system), a cleaning system capable of removing radioactive aerosol from a vented or purged containment atmosphere has some benefit in reducing the calculated radiological consequences ${ }^{(1)}$. This report presents an analytical evaluation of various air cleaning systems for possible use in the FFTF containment margins.

In the postulated melt-through event, a large quantity of sodium aerosol is assumed to be released along with the radioactive species. These sodium compound aerosols impose a higher aerosol mass loading on the present air cleaning system than on normal applications. Therefore, the results of a recent Liquid Metal Fast Breeder Reactor (LMFBR) air cleaning study ${ }^{(3)}$ are not directly applicable.

Objectives of this study are to identify the air cleaning concepts that enhance FFTF containment margins and judge the feasibility of these systems.

Guidelines that limit the scope of this study are:

- Numerous al ternative candidates were el iminated by prescreening on the basis of an earlier study, (3)

- The application does not involve a design basis accident and the system is not required to meet all the requirements of an engineered saf ety system,

- In-containment cleanup devices were not considered, and

- Engineering trade-off studies necessary for final selection of systems were beyond the scope of this report. 


\section{AIR CLEANING REQUIREMENTS}

\section{A. BASIS}

The design operating conditions used in the present evaluation are described in the following sections of this report. The conditions are arbitrarily spec ified, but are believed to represent bounding-case accident scenarios as described by Bankert, et al. (1)

All conceptual designs developed in the present study are based on venting requirements alone. Because venting conditions are much more demanding than purging operations, a system designed for venting can easily handle purge cases. Only the purge $f$ an and valving are different, and these differences are unimportant in the present evaluation.

\section{B. THERMAL CONDITIONS}

For vent mode operation, gas temperatures can vary from $21^{\circ} \mathrm{C}\left(70^{\circ} \mathrm{F}\right)$ to $371^{\circ} \mathrm{C}$ $\left(700^{\circ} \mathrm{F}\right)$, depending on the energy released to the containment atmosphere. The purge mode involves temperatures in the range of $21^{\circ} \mathrm{C}\left(70^{\circ} \mathrm{F}\right)$ to $121^{\circ} \mathrm{C}$ $\left(250^{\circ} \mathrm{F}\right)$. The upper-limit, temperature-time history shown in Figure 1 is used for thermal analyses in this study.

Because the flow control valve is downstream from the air cleaner, pressure in the air cleaning system is equal to that in the containment vessel after venting is initiated. The expected peak pressure is $0.184 \mathrm{MPa}$ absolute (12 psig). The variation in maxiumum pressure with time is shown in Figure 2. 


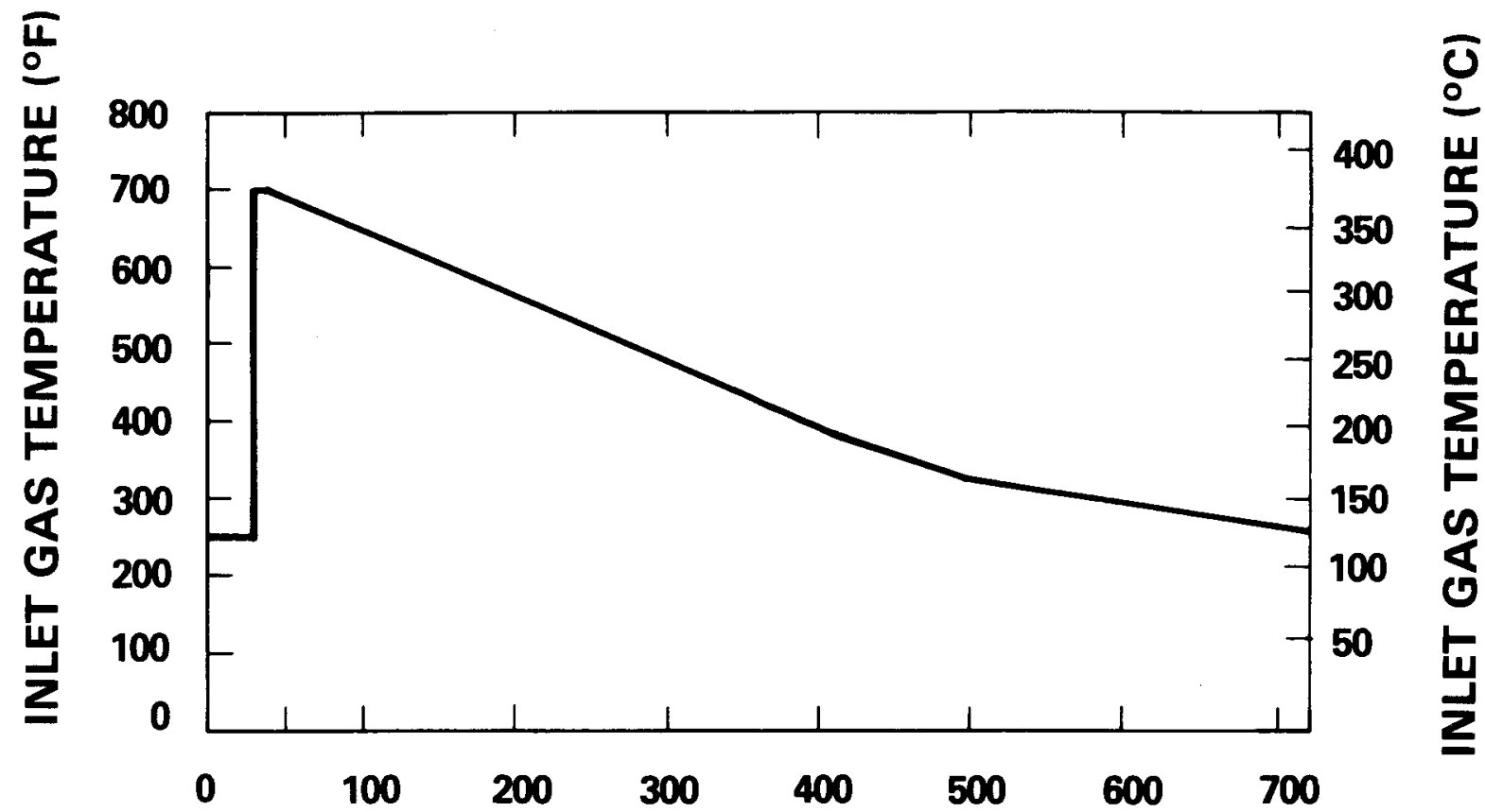

TIME (HR)

HEDL 7912-032.1

FIGURE 1. Maximum Temperature of Air Entering the Air Cleaning System. Neg 8009286-10

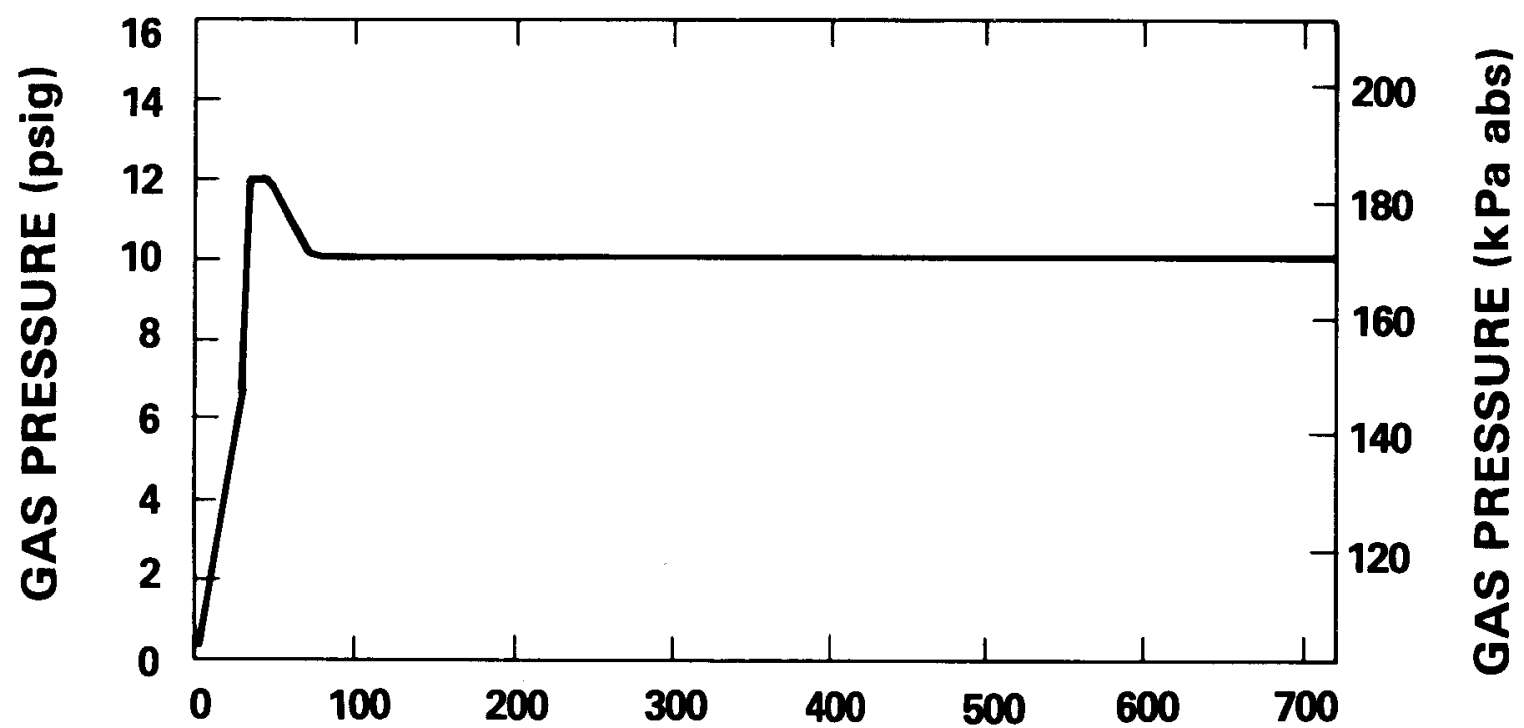

TIME (HR)

HEDL 7912-032.12

FIGURE 2. Maximum Gas Pressure in the Air Cleaning System. Neg 8009286-9 


\section{CHEMICAL FORMS OF GASES AND AEROSOLS}

In a hypothetical breach of containment accident, the initial air atmosphere in the containment vessel is altered by water released from heated concrete and by sodium combustion processes. The composition of gases entering the air cleaning system is shown in Figure 3 as a function of time.

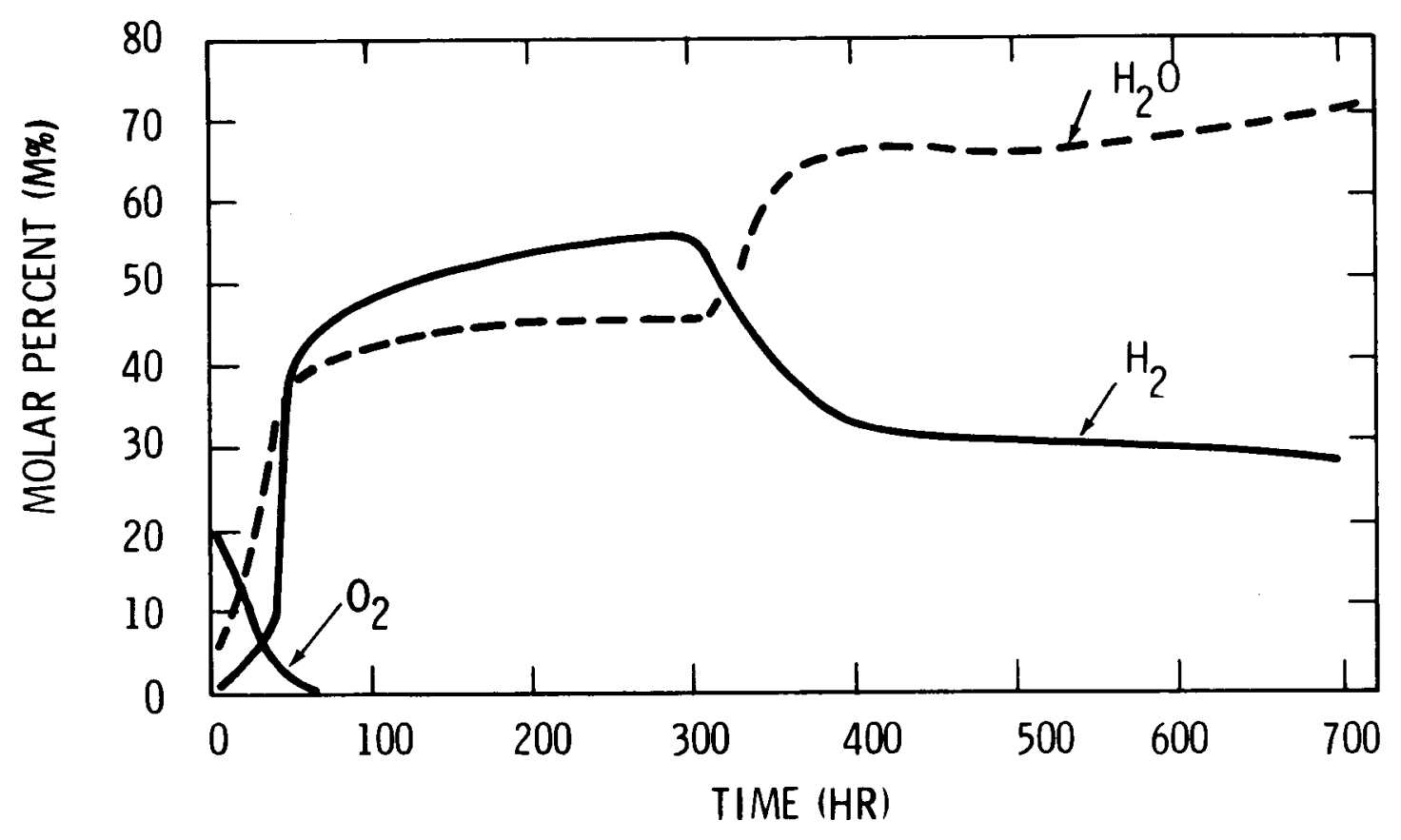

FIGURE 3. Composition of In let Gas. Neg 8009286-8

Initially, sodium entering the containment reacts with $\mathrm{O}_{2}$ to form $\mathrm{Na}_{2} \mathrm{O}_{2}$ :

$$
2 \mathrm{Na}+\mathrm{O}_{2} \longrightarrow \mathrm{Na}_{2} \mathrm{O}_{2}
$$

By the time the air cleaning system is in operation $(30.5 \mathrm{~h})$ appreciable water vapor is present and sodium peroxide is converted to $\mathrm{NaOH}$ with the liberation of $\mathrm{O}_{2}$ :

$$
\mathrm{Na}_{2} \mathrm{O}_{2}+\mathrm{H}_{2} \mathrm{O} \longrightarrow 2 \mathrm{NaOH}+1 / 2 \mathrm{O}_{2}
$$


Excess $\mathrm{H}_{2} \mathrm{O}$ vapor sorption by the $\mathrm{NaOH}$ particles depends on relative humid ity:

$$
\mathrm{NaOH}+\mathrm{xH}_{2} \mathrm{O} \rightleftharpoons \mathrm{NaOH} \cdot \mathrm{xH}_{2} \mathrm{O}
$$

Airborne particles are either dry, sticky or mist drops of $\mathrm{NaOH}$ solution, depending on the relative humidity.

Later, when $\mathrm{O}_{2}$ is depleted, $\mathrm{NaOH}$ is formed directly by the reaction between $\mathrm{Na}$ and $\mathrm{H}_{2} \mathrm{O}$ :

$$
\mathrm{Na}+\mathrm{H}_{2} \mathrm{O} \longrightarrow \mathrm{NaOH}+1 / 2 \mathrm{H}_{2}
$$

Based on the gaseous composition shown in Figure 3, the aerosol particles are composed primarily of $\mathrm{NaOH}$ with varying amounts of hydration.

To insure that solubility-based water requirements are not underestimated, $50 \%$ of the sodium aerosol is assumed to be present in the air cleaner as $\mathrm{Na}_{2} \mathrm{CO}_{3}$. Sodium carbonate is formed if $\mathrm{CO}_{2}$ is released with water from heated concrete, ${ }^{(4)}$ reacting with $\mathrm{NaOH}$ :

$$
2 \mathrm{NaOH}+\mathrm{CO}_{2} \longrightarrow \mathrm{Na}_{2} \mathrm{CO}_{3}+\mathrm{H}_{2} \mathrm{O}
$$

Fifty percent carbonate is probably a conservative value because of the low potential for $\mathrm{CO}_{2}$ release in the FFTF, but scrubber water volumes designed on this bas is will be adequate.

\section{AEROSOL PARTICLE SIZE DISTRIBUTION}

The particle size distribution of the aerosol entering the air cleaning system is assumed to be log normal, with an aerodynamic mass median diameter (AMMD) of $5.57 \mu \mathrm{m}$ and a geometric standard deviation of 2.8. The particle size distribution is plotted on log-probability paper in Figure 4. 


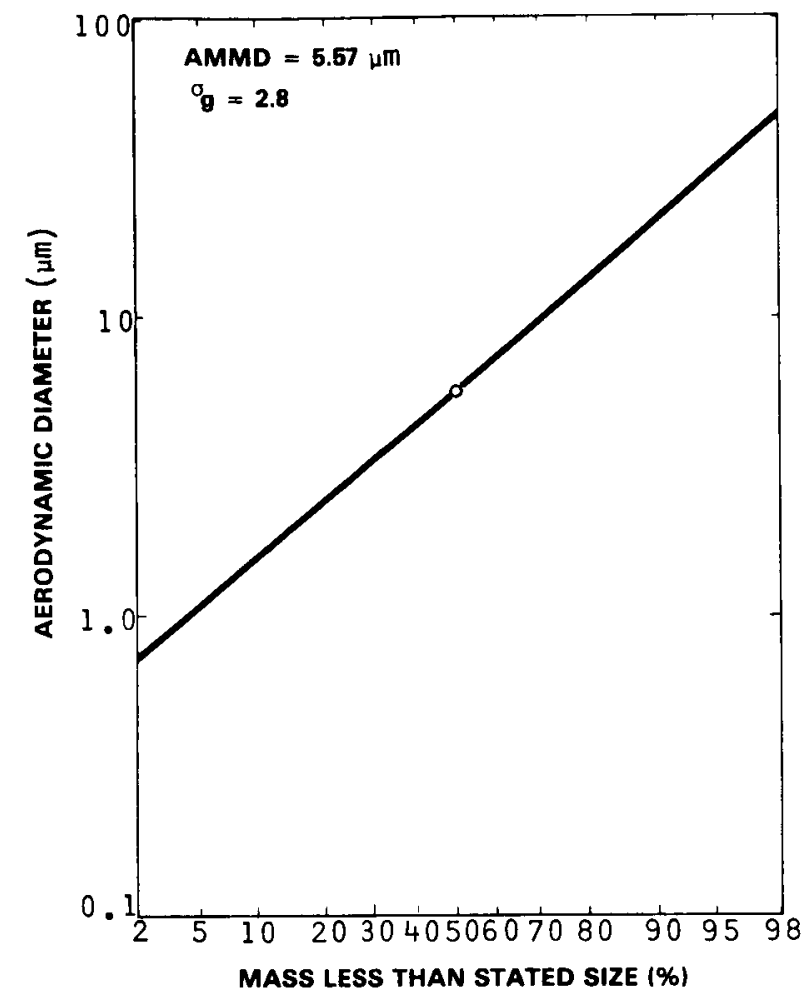

HEDL $8005-171$

FIGURE 4. Particle Size Distribution. Neg 8009286-1

\section{E. GAS FLOW RATE}

Gas flow rate varies with time according to the pressure buildup rate in containment. The maximum flow rate of $3.07 \mathrm{~m}^{3} / \mathrm{s}$ (6500 ACFM) at $371^{\circ} \mathrm{C}$ $\left(700^{\circ} \mathrm{F}\right)$ and $0.184 \mathrm{MPa}(12 \mathrm{psig})$ occurs when venting begins. The flow rate versus time history used for the conceptual designs in this report is shown in Figure 5.

In actual use, the venting would probably be stopped periodically to maintain constant containment pressure. Therefore, Figure 5 should not be used as a basis for estimating total aerosol mass collection by the air cleaning system.

\section{F. AEROSOL MASS COLLECTION}

Based on code analyses of venting rates and aerosol concentrations, the maximum aerosol carried into the air cleaning system is projected to be $5440 \mathrm{~kg}(12,000 \mathrm{lb})$ anhydrous $\mathrm{NaOH}$. 


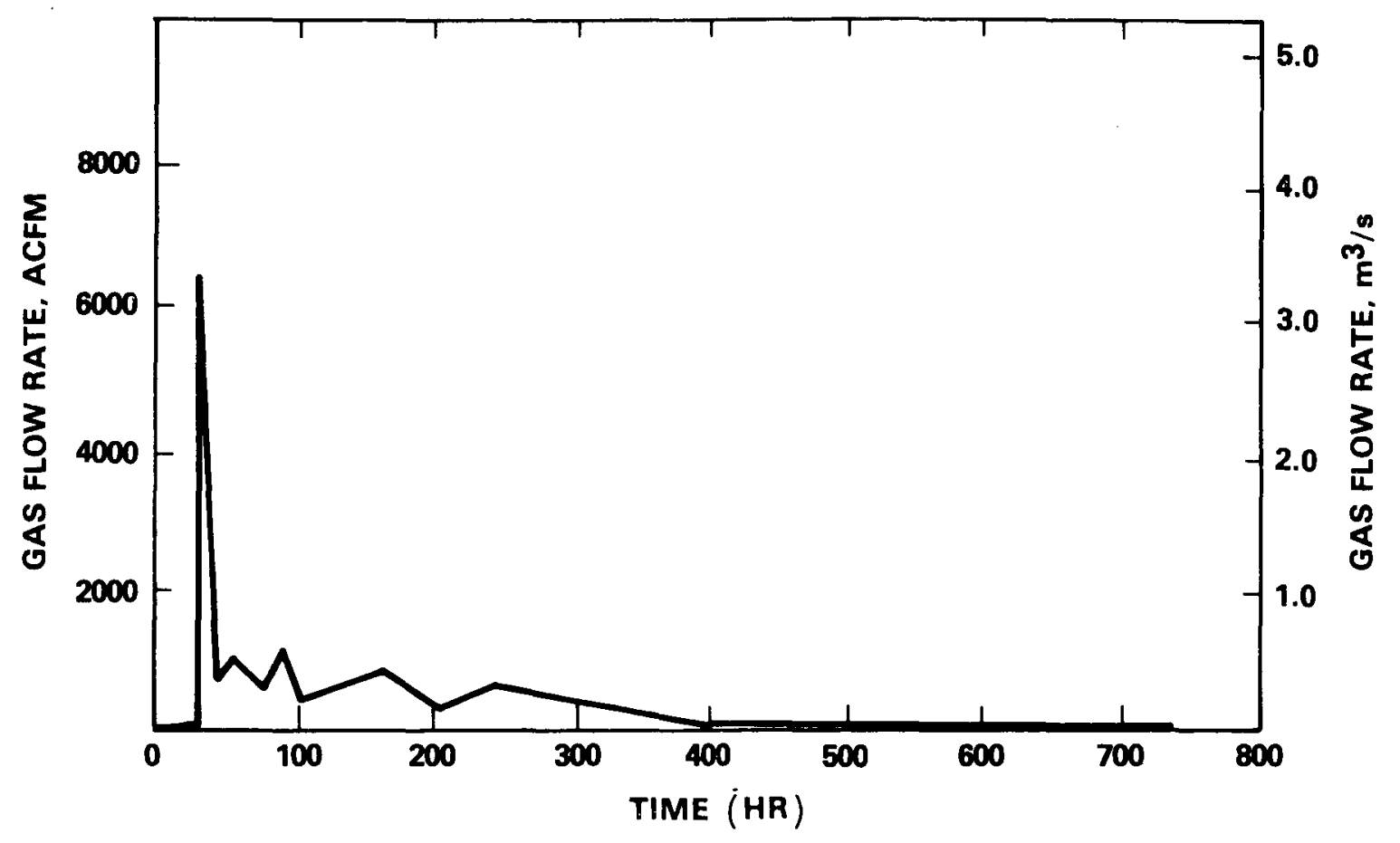

HEDL 7912-032.3

FIGURE 5. Gas Flow Rate.

\section{G. REQUIRED REMOVAL EFFICIENCY}

To provide information on the relative cost and complexity as a function of air cleaning system effectiveness, the study is performed for two classes of systems. For the first class, a $90 \%$ aerosol mass removal efficiency is specified; for the second class, a $99 \%$ efficiency is required.

\section{H. COMPARISON OF DESIGN PARAMETERS}

Air cleaning requirements for the FFTF containment margins application are found to resemble the "containment/confinement" system treated in a recent HEDL evaluation of air cleaning concepts. (3) (See Table 1). However, the higher masses of aerosol and the higher temperatures required by the present study prevent direct utilization of the previous results. 
TABLE 1

COMPARISON OF AIR CLEANING SYSTEM REQUIREMENTS

Parameter

Aerosol Source

Maximum Gas Temperature ( $O C)$

Fl ow Mode

Flow Rate $\left(\mathrm{m}^{3} / \mathrm{s}\right)$

Aerosol Mass Collected as $\mathrm{NaOH}(\mathrm{kg}) \quad 1000$

Max Aerosol Concentration as

$\mathrm{NaOH}$ at Inlet Conditions $\left(\mathrm{g} / \mathrm{m}^{3}\right)$

Aerosol Particle Properties:

Mass Median Diameter ( $\mu \mathrm{m})$

Geometric Std Deviation

Density, $\alpha \rho\left(\mathrm{g} / \mathrm{cm}^{3}\right)$

Aerodynamic Mass Median

Diameter $(\mu \mathrm{m})$

Chemical Composition

$\mathrm{NaOH}$

0

24

Operational Duration (h)
FFTF Margins

Melt-Through and Sodium Boiloff

370

Variable

$3.1 \max$ 0 min

5450

50

7.4

2.8

0.58

5.57

$\mathrm{NaOH}$ with Variable $\mathrm{NaO}_{X}$, $\mathrm{Na}, \mathrm{Na}_{2} \mathrm{CO}_{2}$, Partial Hydration $30.5 *$ 720

* Reactor vessel melt-through assumed to occur 3 hours after HCDA initiation. 


\section{PRELIMINARY SCREENING OF AIR CLEANING CONCEPTS}

The large list of air cleaning concepts identified in an earlier study (3) was screened to identify prime candidates for FFTF margins application. See Table 2. The following requirements eliminated many candidates:

- Aerosol mass loading is high $(5450 \mathrm{~kg})$.

- Concept technology must be at a state of development where hardware design can be started immediately.

- Only one of several apparently equivalent concepts was considered.

- Concepts involving in-containment cleaning were outside the scope of FFTF margins application and therefore were eliminated.

- Systems requiring gas recirculation were not considered.

Seven air cleaning systems were selected for evaluation. Four of these were designed to collect $99 \%$ or more of incident aerosol and three were designed to collect $90 \%$ or more.

The systems evaluated are:

\section{Case I - 90\% Efficient}

LE-1 - Eductor Venturi

LE-2 - Spray Chamber

LE-3 - Submerged Grave 1 Bed

\section{Case II- 99\% Efficient}

HE-1 - Spray Quench/Eductor Venturi/Fibrous Scrubber

HE-2 - Submerged Gravel Bed/Fibrous Scrubber

HE-3 - Sand and Grave 1 Bed

HE-4 - HEPA Filters 


\section{Air Cleaning Concept}

Reason

Eliminated

Filters:

Industrial Prefilters

Deep Bed Graded Media

Bag Filters

Sand and Gravel Bed

High Efficiency Particulate Air (HEPA)

Cyclone Separator

Mechanical Separator

Dry Electrostatic Precipitator

Wet Electrostatic Precipitator

Wet Scrubbers:

Spray Chamber

Fibrous Packing (10w efficiency type)

(b)

(a)

High Density Fiber Bed

Packed Bed (e.g., gravel or Rashig rings)

Venturi

Centifuga 1

Settling Chamber

Acoustic Agglomerator

Fluidized Bed

(b), (c)

Foam Dispersal

(a), (b), (c)
(a) Low Mass Loading Capability
(b) Low or Uncertain Efficiency
(c) Uncertain Behavior for Margins Application
(d) Overall Performance Similar to Other Systems Being Evaluated 


\section{CRITERIA FOR RANKING ALTERNATIVE SYSTEMS}

The criteria used in a previous air cleaning study ${ }^{(3)}$ were modified for application to FFTF containment margins. The six criteria groups are listed in Table 3. Each group contains several individual criteria listed in Table 4. Each criterion is assigned a weight factor to measure its relative importance. The total weight is adjusted to 100.

To rank the various systems, a scoring system was devised as shown in Table 5. A score of 0 to 4 is assigned to each air cleaning system on a criterion-bycriterion basis.

The rating definition is measured by the amount of development work required. However, the same rating factors are used to indicate the acceptability of intrinsic characteristics. For example, the efficiency of a spray chamber is, by the physical forces involved, very dependent on particle size; and no amount of development will change that dependence.

A system score is determined by summing indiviudal criterion scores (the product of the criterion weight and the rating factor). The maximum possible system score is 400 .

The following steps sumarize the evaluation procedure:

- Definition of the system, including a preliminary conceptual design, utilizing the aerosol and containment atmosphere parameters listed in Section 3.

- The system is evaluated by the criteria listed in Table 4.

- The degree to which the system meets the criteria is quantified by assigning a rating factor ranging from 0 to 4 (to the nearest 0.1 ), based on criteria described in Table 5. 
TABLE 3

AIR CLEANING EVALUATION CRITERIA GROUPS

$\frac{\text { Group No. }}{1} \quad \frac{\text { Group Weight }}{17} \quad \frac{\text { Criterion Description }}{\text { System Effectiveness }}$

The system shall be effective in reducing the release of radioactive substances to the environment.

$26 \quad$ System Reliability

The system shall have a high degree of reliability in startup and continuance of operation during the entire accident period.

$9 \quad$ Containment Compatibility

The presence and operation of the system shall not degrade the normal effectiveness of the containment building.

22 Technological Credibility

The effectivieness of the system shall be clearly demonstrable by experience, mathematical models and testing.

12 System Characteristics and Flexibility

The system performance shall not be critically dependent on the accident environment conditions and shall accommodate possible future design changes.

The system shall be readily designed, fabricated and installed at reasonable cost and in a time frame consistent with plant construction. 
TABLE 4

EVALUATION CRITERIA FOR AIR CLEANING SYSTEMS

\section{Criteria Description}

\section{SYSTEM EFFECTIVENESS}

*a. The design decontamination factor can be achieved using design parameters that fall within current state-of-the-art practice.

$\star_{d}$. The system can handle dry or sticky particles and particles of varying chemical composition.

${ }^{\star} c$. System effectiveness is not degraded by the radiation dose caused by the accident over the required operating period.

d Characteristics inherently favor the system's ability to handle 1 arge masses of aerosol.

2. SYSTEM RELIABILITY

*a. System shall have a high probability of startup after initiation of the accident.

*b. System does not degrade during non-use periods.

${ }^{*}$ c. System shall be capable of dependable operation over a 1000-hour accident period under accident conditions of temperature, humidity, aerosol loading and flow rate.

d. System requires simple components, control and conservative design stresses.

3. CONTAINMENT SYSTEM COMPATIBILITY

*a. Inadvertent operation shall not harm the containment system or constitute a hazard to personnel.

b. Size shall be compatible with installation adjacent to the RCB, and not significantly impact the location of other ancillary plant systems.
Weight Factor

Total: 17

5

5

2

5

Total: $\underline{26}$

9

6

8

3

Total: $\underline{9}$

4

5

*Denotes criteria with mandatory acceptable ratings. 
TABLE 4 (Cont'd)

\section{Criteria Description}

4. TECHNOLOGICAL CREDIBILITY

a. Air cleaning concept is based on highly developed technology.

*b. System can be tested in-place for operability and efficiency.

c. System performance can be predicted by verified mathematical models.

d. System equipment scaleup from currently available sizes to LMFBR plant application is small.

e. System concept has been demonstrated with sodium aerosol or the extension of results to sodium aerosol can be made with confidence.

5. SYSTEM CHARACTERISTICS AND FLEXIBILITY

a. System is effective for the entire particle size spectrum expected during the accident.

b. System performance is not highly sensitive to the atmospheric temperature or relative humidity.

c. System energy consumption is low.

d. Post-accident recovery is facilitated by the EACS.

6. FABRICATION EFFORT

a. System costs, capital and maintenance, are low.

b. Materials and techniques used in construction are readily available and easily fabricated.

c. Components and equipment are readily available.
Weight Factor

Total: $\underline{22}$

5

6

5

3

3

Total: 12

3

3

3

3

Tota 1: $\underline{14}$

10

2

2

$100 \quad \overline{100}$

*Denotes criteria with mandatory acceptable ratings. 
TABLE 5

RATING FACTORS FOR AIR CLEANING SYSTEMS

\begin{tabular}{|c|c|c|}
\hline $\begin{array}{l}\text { Rating } \\
\text { Factor }\end{array}$ & \multicolumn{2}{|c|}{ Rating Description } \\
\hline 4 & Clearly acceptable & Completely satisfies criterion. \\
\hline 3 & Probably acceptable & $\begin{array}{l}\text { Some development may be required. } \\
\text { May not completely meet the crite- } \\
\text { rion but is adequate. }\end{array}$ \\
\hline 2 & Possibly acceptable & $\begin{array}{l}\text { A large development effort may be } \\
\text { required. Barely meets or falls } \\
\text { short of the criterion. }\end{array}$ \\
\hline 1 & Probably unacceptable & Low probably of meeting criterion. \\
\hline 0 & Clearly unacceptable & $\begin{array}{l}\text { Zero probability of meeting the } \\
\text { criterion. }\end{array}$ \\
\hline
\end{tabular}

Because certain criteria were considered mandatory requirements, a score of 2.0 or better was required for the system to be considered feasible. Mandatory criteria are listed in Table 6.

\section{TABLE 6}

CRITERIA WITH MANDATORY ACCEPTABLE RATINGS*

Criterion No.

$1 \mathrm{a}$

$1 b$

1c

$2 \mathrm{a}$

$2 b$

$2 \mathrm{c}$

$3 a$

$4 b$
Description

Removal efficiency is state-of-art

Dry or sticky particles

Radiation resistance

Reliable startup

Storage 1 ife

Reliable long-term operation

Inadvertent operation

In-place testability

*Acceptable is defined as a minimum rating factor of 2.0 , as described in Table 5 . 
- The system score for each individual criterion is obtained by multiplying the criterion weight factor (Table 4) by the assigned rating factor.

- The overall system rating is calculated by summing the scores of the individual criteria. The maximum possible score is 400 .

- Systems having a low rating for any individual criterion are examined for possible design changes to improve their rating.

- The systems are ranked according to total score.

- Final ranking is made by considering both the numerical score and the probability of successful application. Because many of the criteria are only semi-quantifiable, the evaluation and rating necessarily entail considerable judgement. 


\section{EVALUATION RESULTS}

A rudimentary conceptual design was made for each of the seven systems selected in Section IV. Although the designs are not necessarily optimum, this is not expected to have a major influence in comparing systems except where two systems are closely equivalent.

The component and system designs in this study were based on information developed in an earlier study. (3) Where available, equipment performance with sodium or sodium oxide aerosols was used. In the absence of operating performance data specific to LMFBR accident conditions, published information for standard air pollution control equipment was used. Modifications for LMFBR conditions were made according to the authors' judgment.

A cost estimate was made for each system based primarily on component costs developed in an earlier study. (3) The costs include engineering, equipment, installation labor, instrumentation and the building needed to house the equipment. The cost estimates are presented as arbitrary units for comparison purposes.

\section{A. DESCRIPTION OF SYSTEMS DESIGNED FOR 90\% EFFICIENCY}

Three air cleaning concepts were selected as candidates for $90 \%$ efficient systems. All three are aqueous scrubbers and are judged as the prime candidate systems available for application to FFTF margins. The candidate systems are shown schematically in Figure 6 .

\section{Venturi Scrubber - System LE-1}

System LE-1 employs an eductor venturi scrubber to remove airborne particles. An eductor-type venturi was selected over a gas-atomized-type venturi because removal efficiency increases as gas flow rate decreases in an eductor unit. In this study the gas flow rate may vary from zero to the design maximum; therefore, use of a gas-atomized venturi would introduce 


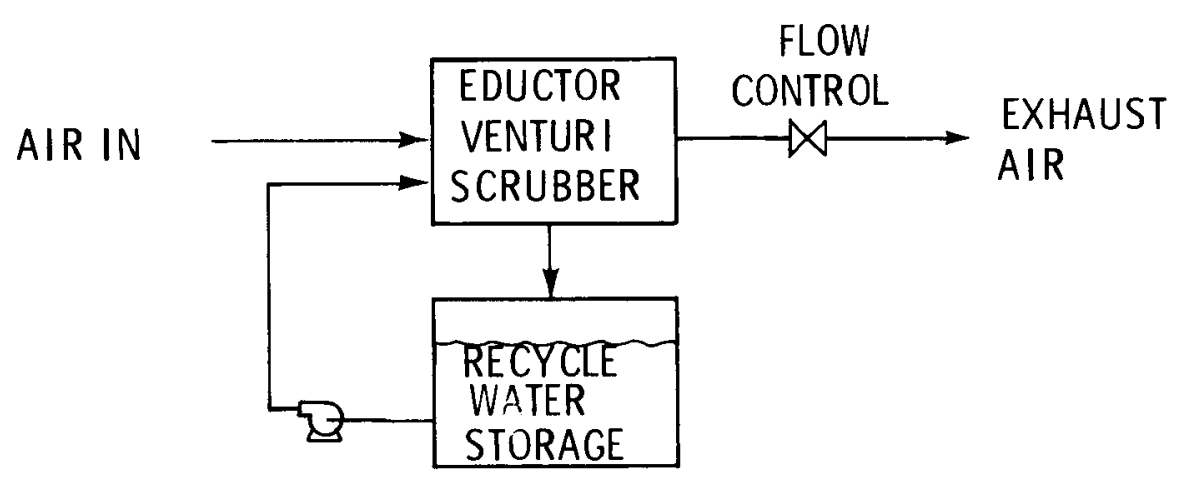

VENTURI SCRUBBER - SYSTEM LE-I

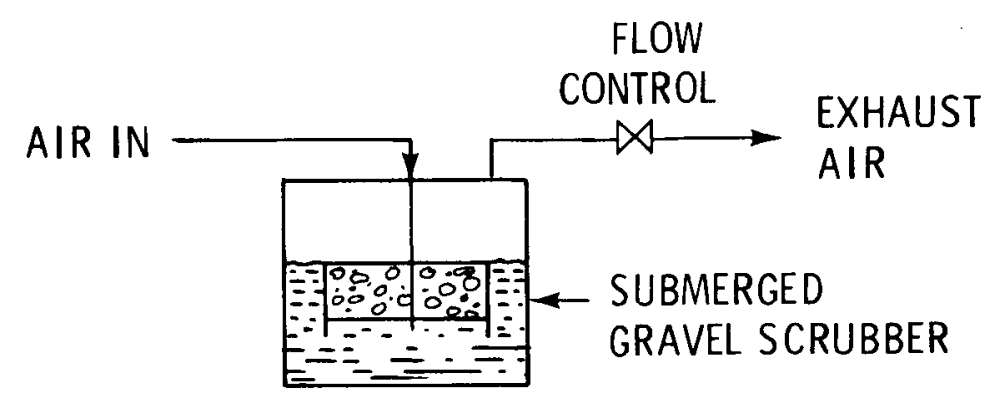

SUBMERGED GRAVEL SCRUBBER - SYSTEM LE-2

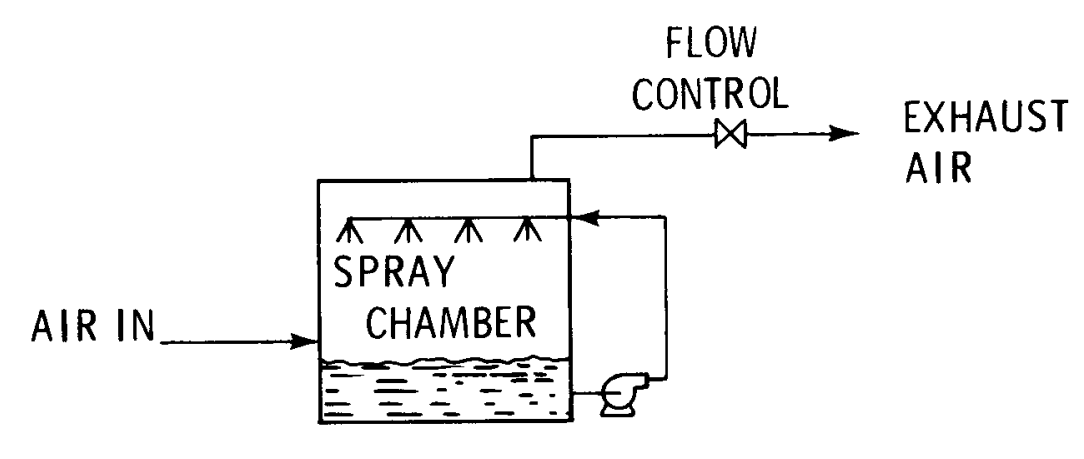

SPRAY CHAMBER SCRUBBER - SYSTEM LE-3

HEDL 7912-032.12

FIGURE 6. Flow Diagrams For 90\% Efficient Candidates. Neg 7913162-12 
design complexities that deal with the loss in removal efficiency when flow rate is decreased from the design value.

The main equipment components in this system are: 1) the venturi and separator, 2) the liquid recirculation spray pump and 3) the liquid storage tank. All three components must be designed to withstand an ambient pressure of $0.184 \mathrm{MPa}$ (12 psig) because containment venting rate is controlled by a valve located downstream from the scrubber.

Particle removal efficiency within the eductor was assessed by drop capture models and by comparison with experimental measurements reported for an eductor venturi scrubber studied at HEDL. (5) The size of the venturi was based on a throat gas velocity of $16 \mathrm{~m} / \mathrm{s}(52 \mathrm{ft} / \mathrm{s})$ and the geometrical proportions used by several equipment manufacturers. The venturi unit, complete with entrainment separator, was estimated to be $5.8 \mathrm{~m}(19 \mathrm{ft})$ in height and $2.3 \mathrm{~m}(7.5 \mathrm{ft})$ in diameter.

The water storage tank holds $30.3 \mathrm{~m}^{3}(8,000 \mathrm{gal})$. The water volume is stipulated by solubility considerations for the collected aerosol material. An elevation view of equipment layout for the venturi scrubber system is shown in Figure 7. Important design parameters for System LE-1 are sumarized in Table 7.

\section{Submerged Gravel Scrubber - System LE-2}

System LE-2 uses a submerged gravel bed to trap airborne particles. This system is novel because the air flow induces water circulation through the gravel bed and makes a separate water pumping system unnecessary. This concept is currently under development at HEDL and a patent application was filed.

In operation, inlet air is dispersed beneath a gravel bed by means of a submerged downcomer. Buoyant forces cause the air to pass upward through the gravel bed. Appreciable volumes of water are entrained with the air 


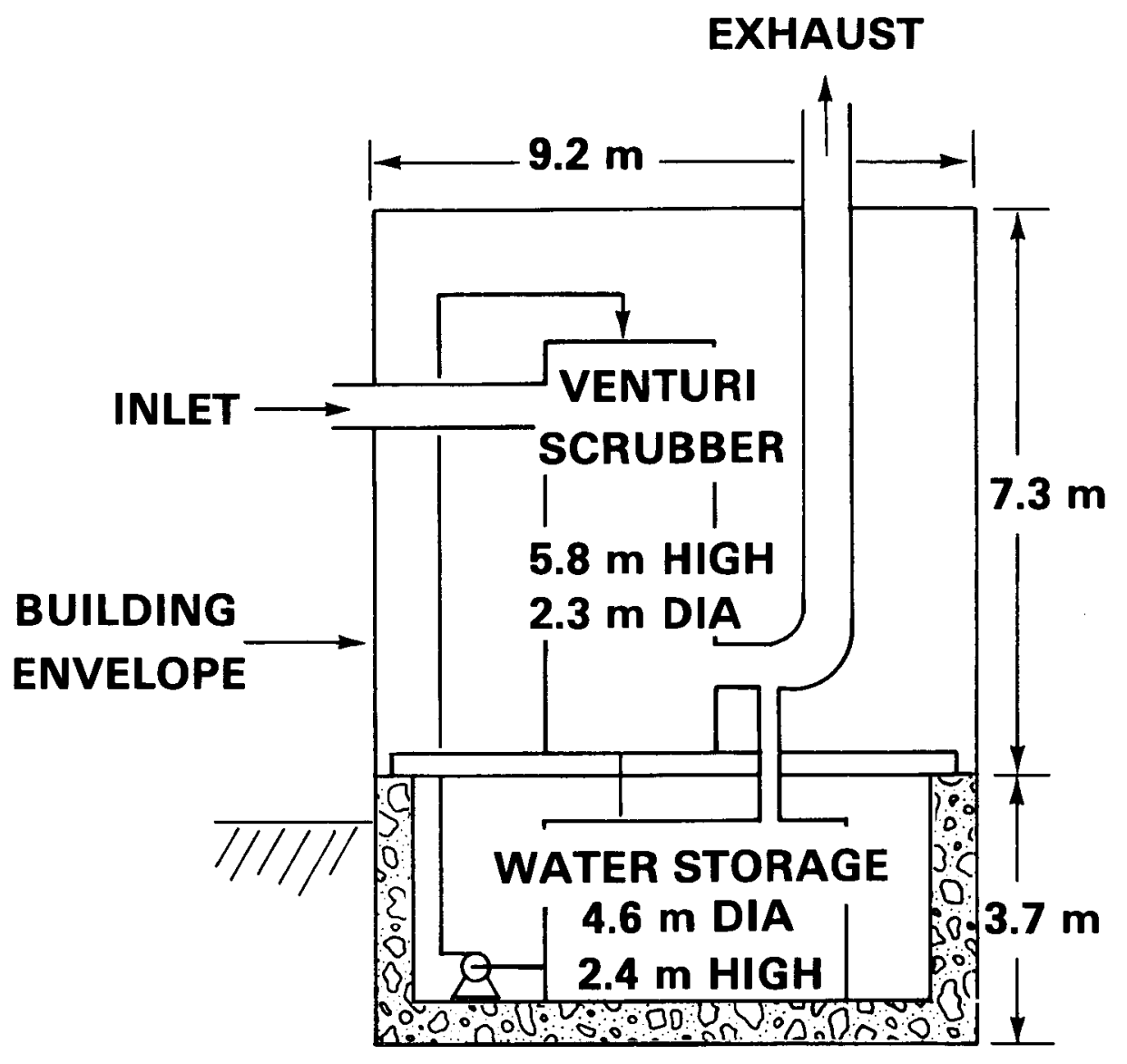

HEDL 7912-032.8

FIGURE 7. Layout For Venturi Scrubber - System LE-1. Neg 8009286-7

TABLE 7

PARAMETERS FOR VENTURI SCRUBBER - SYSTEM LE-1

$\begin{array}{ll}\text { Water Flow Rate } & 1.70 \mathrm{~m}^{3} / \mathrm{min} \text { (450 gal/min) } \\ \text { Water Pressure Drop } & 0.55 \mathrm{MPa} \text { (80 psid) } \\ \text { Throat Gas Velocity } & 16 \mathrm{~m} / \mathrm{s} \mathrm{(52} \mathrm{ft/s)} \\ \text { Max Gas Flow Rate } & 3.07 \mathrm{~m}^{3} / \mathrm{s} \mathrm{(6500} \mathrm{ACFM)} \\ \text { Draft Generated } & 248 \mathrm{~Pa} \mathrm{(1} \mathrm{inch} \mathrm{water)} \\ \text { Particle Removal Efficiency } & 90 \% \\ \text { Relative Cost Units } & 0.80\end{array}$


flow. The circulating water keeps the bed clean of particulate debris and assures that water in the system is nearly isothermal. The submerged grave 1 bed concept is described in Figure 8.

Design of the submerged gravel bed was based on scale-up of results from engineering scale models tested at HEDL. The most important parameters, gas velocity and bed depth, were selected as $0.51 \mathrm{~m} / \mathrm{s}(100 \mathrm{ft} / \mathrm{min})$ and $0.61 \mathrm{~m}$ $(2 \mathrm{ft})$, respectively. Particle removal efficiency was analyzed using an equation for packed beds ${ }^{(6)}$ and comparison with HEDL experiments.

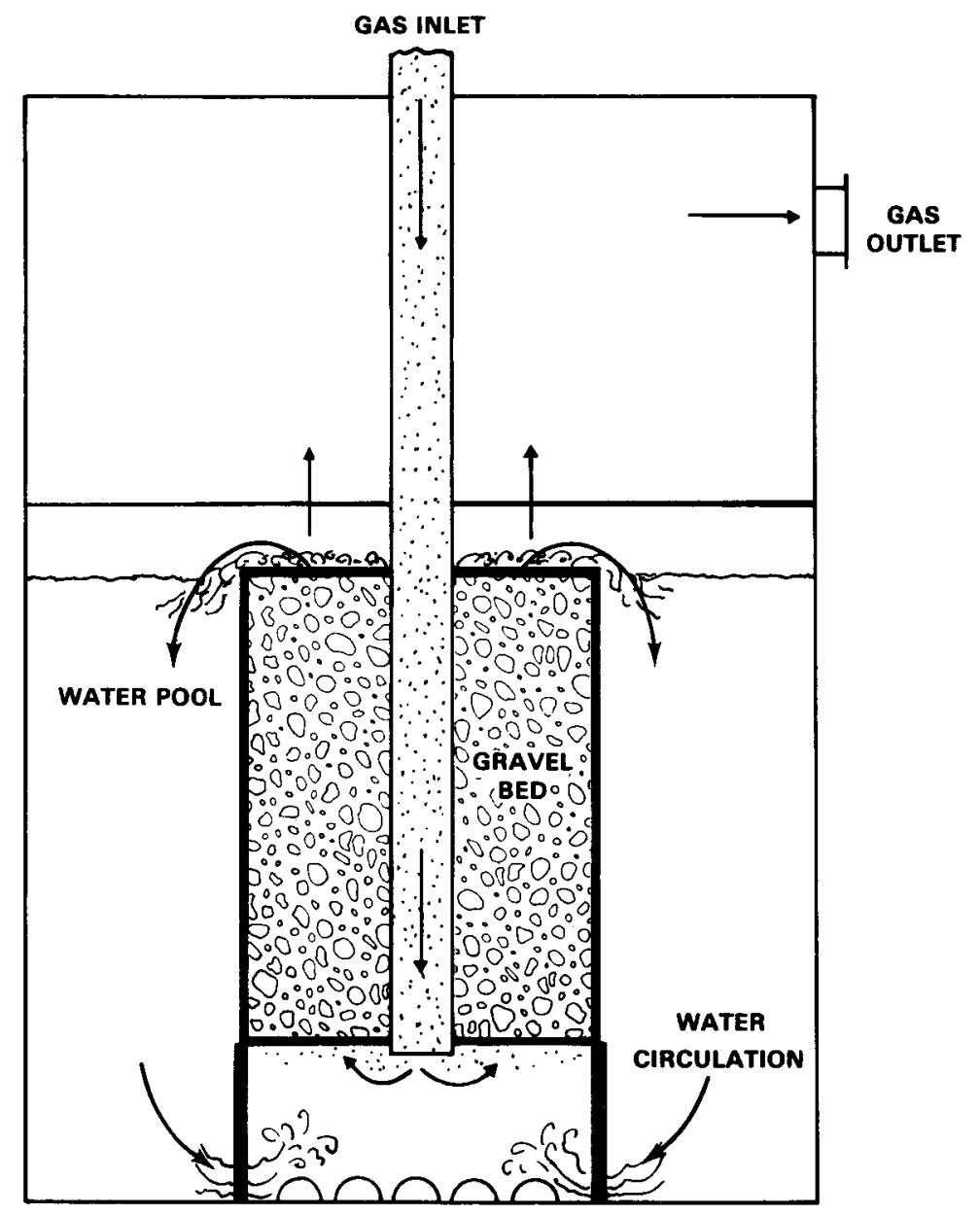

HEDL 7912-052.14

Figure 8. Description of Submerged Gravel Scrubber Concept. Neg 8009286-3 
An elevation view showing the layout of the submerged gravel bed is given in Figure 9. Important parameters that describe the design of the submerged grave 1 bed are sumarized in Table 8 .

\section{EXHAUST}

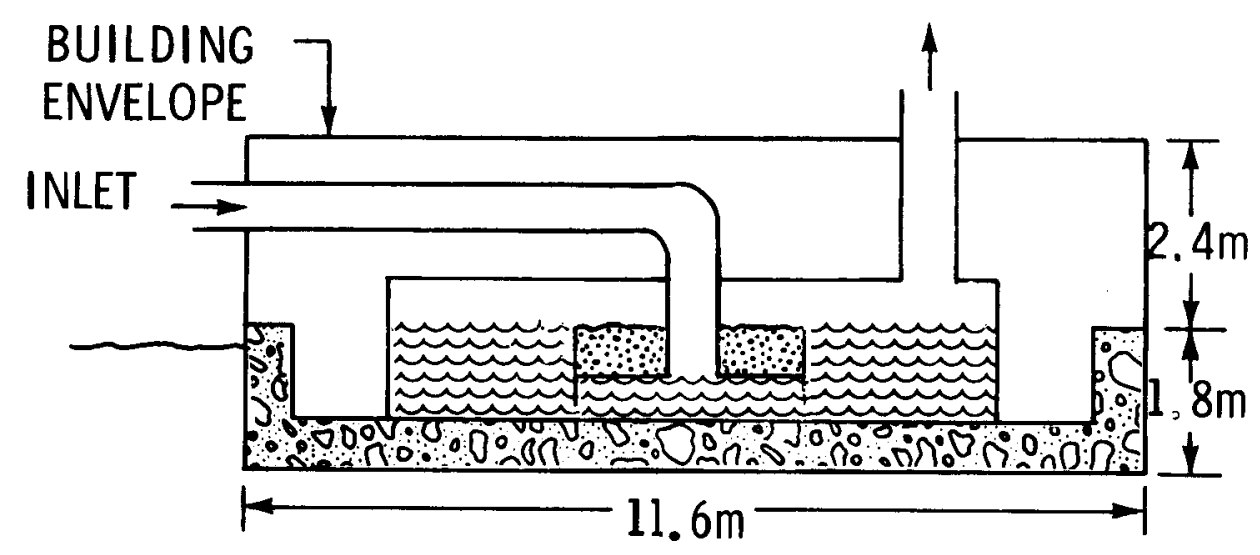

HEDL 7912-032.7

Figure 9. Layout of a Submerged Gravel Scrubber - System LE-2. Neg 8009286-11 TABLE 8

PARAMETERS FOR SUBMERGED GRAVEL SCRUBBER - SYSTEM LE-2

Grave 1 Bed OD

Inlet Downcomer Diameter

Grave 1 Bed Depth

Superficial Gas Velocity

in Gravel (maximum)

Size of Crushed Rock Packing

Volume of Water

Particle Removal Efficiency

Relative Cost Units
$3.05 \mathrm{~m}(10 \mathrm{ft})$

$0.61 \mathrm{~m}(2 \mathrm{ft})$

$0.61 \mathrm{~m}(2 \mathrm{ft})$

$0.51 \mathrm{~m} / \mathrm{s}(100 \mathrm{ft} / \mathrm{min})$

9.5 to $13 \mathrm{~mm}$ ( $3 / 8$ to $1 / 2$ in.) $51.1 \mathrm{~m}^{3}(13,500 \mathrm{gal})$

$90 \%$

0.45 


\section{Spray Chamber - System LE-3}

The spray chamber scrubber is conceptually similar to the eductor venturi in that particle removal is dominated by water drop impaction. The water stream requires higher energy in the venturi but the venturi is smaller in size compared to a spray chamber.

The main component of the spray scrubber is the chamber where falling drops capture suspended particles, mainly by impaction. Due to 1 arge size, recirculating water inventory is accommodated within the chamber itself. A recirculating water pump is required to maintain spray flow.

Spray chamber size was determined by the spray rate required to remove $90 \%$ of airborne particles and by the maximum spray flux that will avoid significant drop coalescence. It was assumed that the gas phase with in the spray chamber was we 11-mixed. The design approach used is supported by results obtained at HEDL on the removal of sodium compound aerosols within a spray quench chamber. (5)

An elevation view showing the size of the spray scrubber is given in Figure 10. The spray scrubber is appreciably larger than the other two candidates (Figures 8 and 9). Important parameters that describe the design of the spray scrubber are summarized in Table 9.

The significantly higher cost of the spray scrubber is mainly due to the larger size. The higher cost and larger size of the spray scrubber indicate that it will not be competitive with the two other scrubbers unless major off-setting advantages are identified in the detailed evaluation.

\section{B. DESCRIPTION OF SYSTEMS DESIGNED FOR 99\% EFFICIENCY}

Four systems were selected as candidates for $99 \%$ efficiency removal - two aqueous scrubbers candidates from the $90 \%$ removal up-graded by adding a packed fiber bed to the outlet of the $90 \%$ scrubber; a sand and gravel bed and a bank 


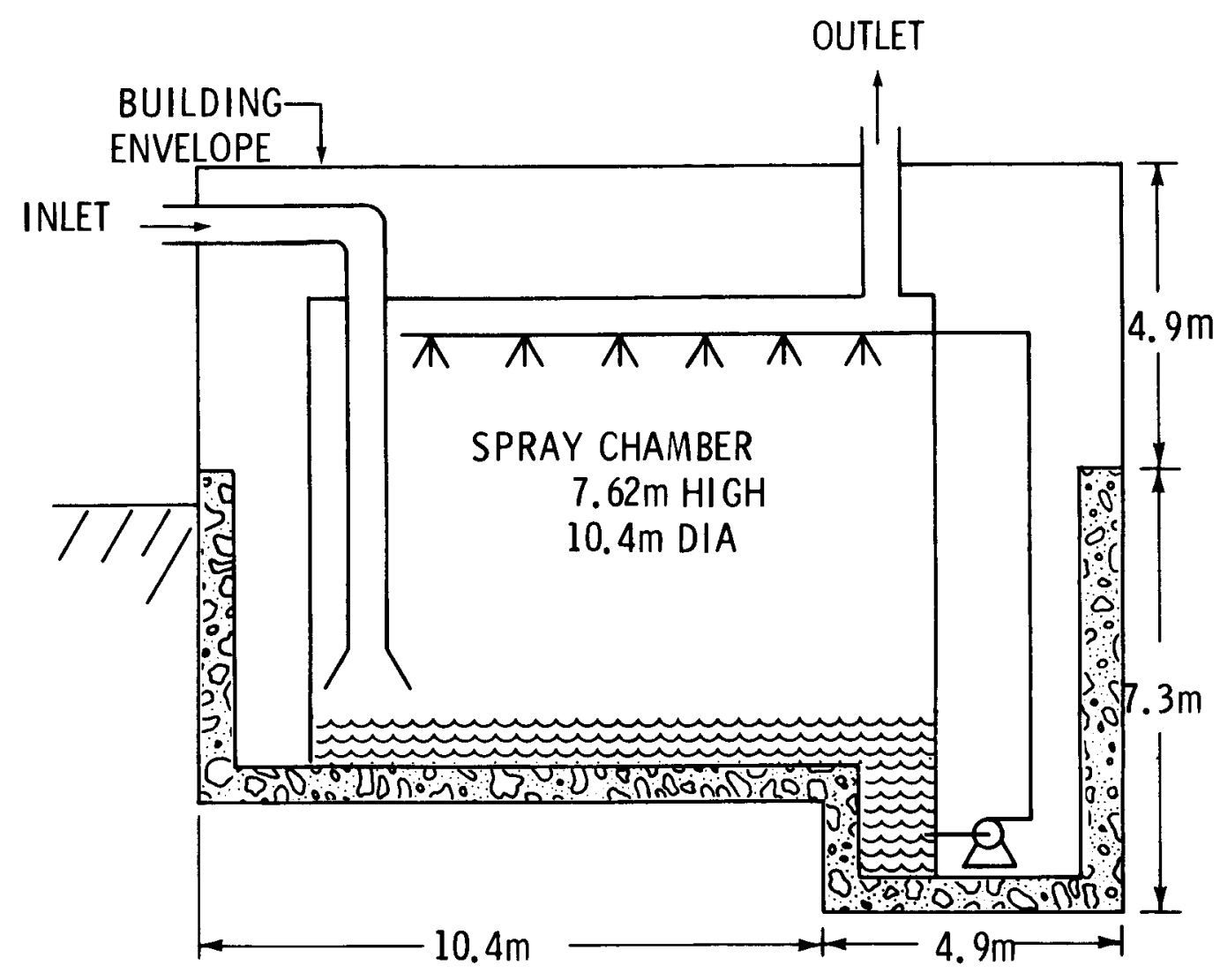

HED L 7912-032.9

FIGURE 10. Layout of Spray Scrubber - System LE-3. Neg 8009286-6

TABLE 9

PARAMETERS FOR SPRAY SCRUBBER- SYSTEM LE-3

Diameter of Spray Chamber

Height of Spray Chamber

Spray Flow Rate

Nozzle Pressure Drop

Volume of Water

Effective Drop Diameter

Flow Rate Per Nozzle

Particle Removal Efficiency

Relative Cost Units
$10.4 \mathrm{~m}(34 \mathrm{ft})$

$7.6 \mathrm{~m}(25 \mathrm{ft})$

$1.70 \mathrm{~m}^{3} / \mathrm{min}$ (450 gal/min)

$0.28 \mathrm{MPa}$ (40 psid)

$30.3 \mathrm{~m}^{3}$ (8000 gal)

$1200 \mu \mathrm{m}$

$0.0473 \mathrm{~m}^{3} / \mathrm{min}(12.5 \mathrm{gal} / \mathrm{min})$

$90 \%$

1.6 
of HEPA filters. Flow diagrams for the candidate systems designed for $99 \%$ removal efficiency are shown in Figure 11.

\section{Venturi Scrubber with Fibrous Backup - System HE-1}

In this system, a packed bed of fibers is added to trap particles that penetrate the venturi. The combined system will yield removal efficiencies well in excess of $99 \%$, as demonstrated in tests performed at $\mathrm{HEDL}^{(5)}$. The design of the venturi pre-scrubber was taken directly from System LE-1 (Figure 7).

The venturi/fibrous scrubber occupies a space envelope cylindrical in shape, $5.8 \mathrm{~m} \mathrm{high}$ and $2.3 \mathrm{~m}$ in diameter. Other design parameters for the venturi scrubber are listed in Table 7.

The venturi/fibrous scrubber design used annular-shape packed beds of polypropylene fibers. The $72.6-\mathrm{mm}$ ( $3-\mathrm{in}_{\text {.) }}$ thick annulus is $0.59 \mathrm{~m}$ (18 in.) inside diameter, $0.79 \mathrm{~m}$ (24 in.) outside diameter and $3.05 \mathrm{~m}(10 \mathrm{ft})$ in length. Four elements are required to handle the maximum gas flow rate of $1.75 / \mathrm{m}^{3} / \mathrm{s}$ (3700 ACFM) exiting from the venturi scrubber. Fresh process water mist is applied to the upstream surface of the bed to assure that all soluble material is washed from the fibers. The spray mist flow rate was $20.8 \mathrm{~cm} / \mathrm{s}(0.33 \mathrm{gal} / \mathrm{min})$. The venturi/fibrous scrubber elements were enclosed in a carbon steel tank.

This system requires a recirculation water tank appreciably larger than that used in the $90 \%$ design to accommodate the process water used to wet the fiber beds. Over an operating time of 720 hours, $54.5 \mathrm{~m}^{3}$ (14,400 gal) of water would be added as spray mist to the $30.3 \mathrm{~m}^{3}$ ( $\left.8000 \mathrm{gal}\right)$ of water required for 

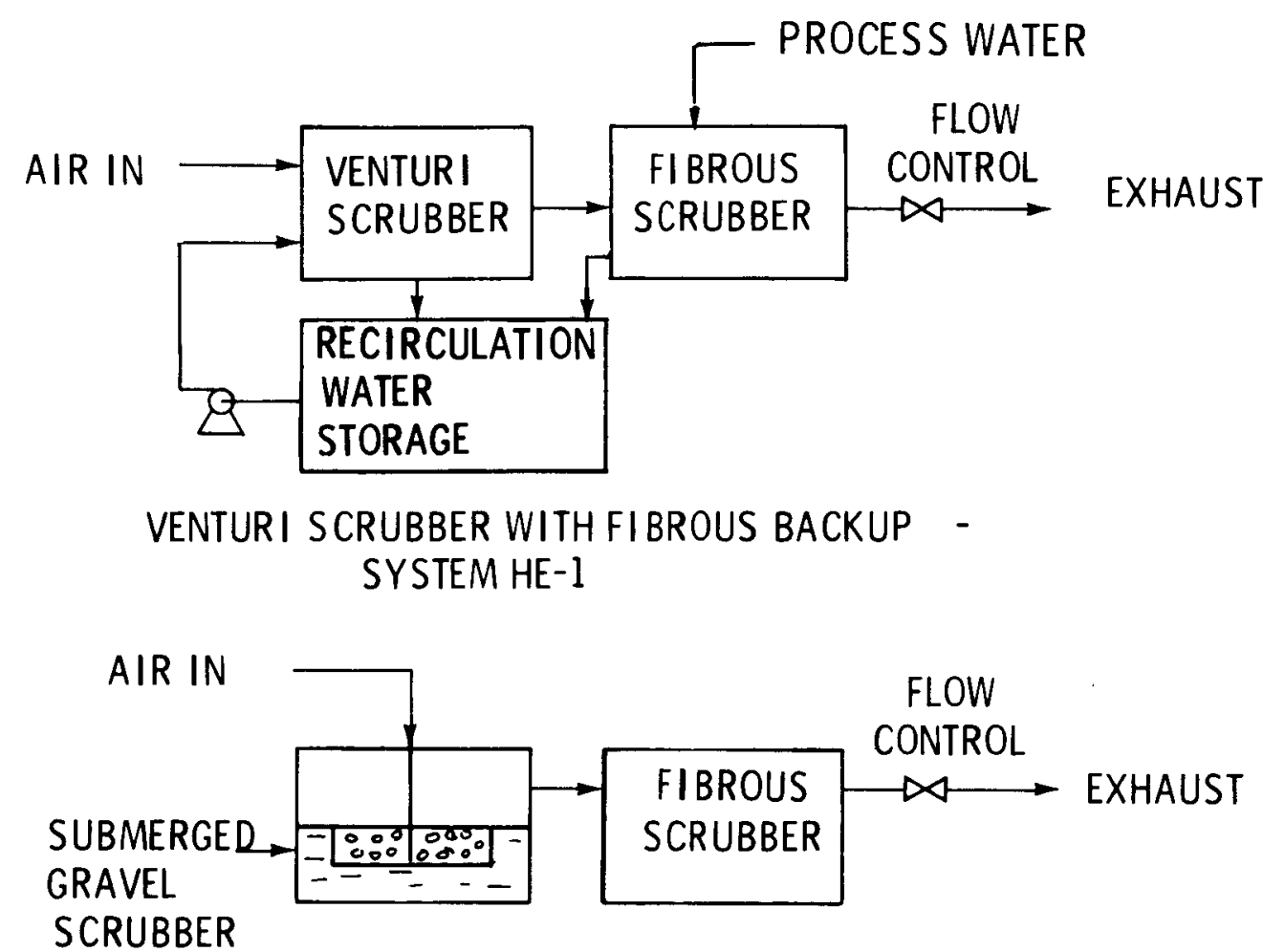

SUBMERGED GRAVEL SCRUBBER WITH FIBROUS BACKUP SYSTEM HE-2 FLOW

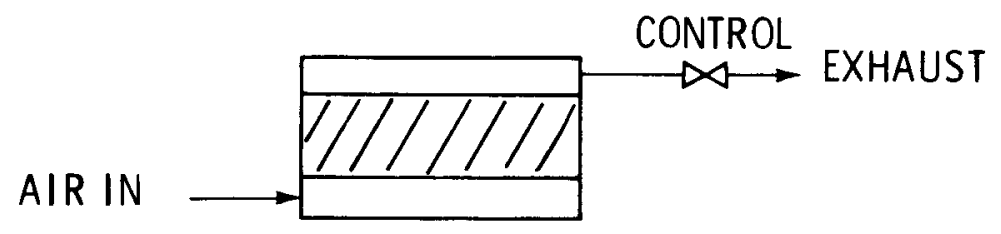

SAND AND GRAVEL FILTER - SYSTEM HE-3

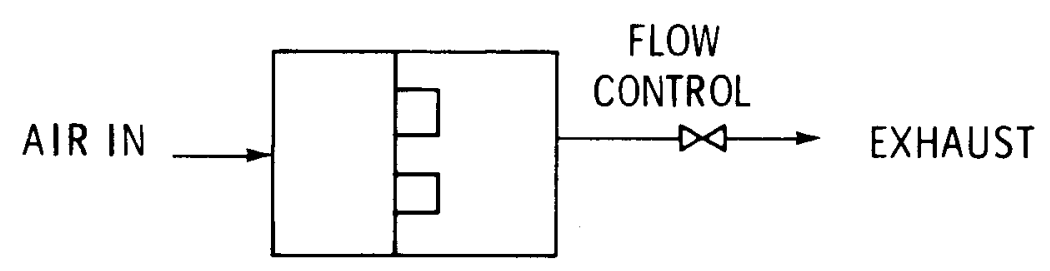

HEPA FILTER BANK - SYSTEM HE-4

HEDL 791 2-032.13

FIGURE 11. Flow Diagrams For 99\% Efficient Candidate Systems. Neg 8009286-5 
solubility for a total minimum liquid capacity of $84.8 \mathrm{~m}^{3}(22,400 \mathrm{gal})$. A tank having a volume of $113.6 \mathrm{~m}^{3}(30,000 \mathrm{gal})$ was specified to account for potential condensate accumulation and gas space margin requirements.

An alternative bed washing scheme using recycled water could in principle be used to minimize storage tank capacity. Such a scheme would require a filtration device to avoid plugging the spray nozzle. Only fresh water wash was considered.

An elevation view of the conceptual design for System HE-1 is given in Figure 12. Design parameters for the venturi/fibrous scrubber are summarized in Table 10.

The data of Table 10 show that a cost increment of $25 \%$ is added to the $90 \%$ efficient venturi scrubber system to increase the removal efficiency to $99 \%$. Also, the spatial requirements are $50 \%$ greater. However, this system is less costly than the $90 \%$ spray scrubber. Unless a detrimental characteristic is borne out in the detailed ranking process, this $99 \%$ system is preferred compared to a lower efficiency, higher cost spray scrubber.

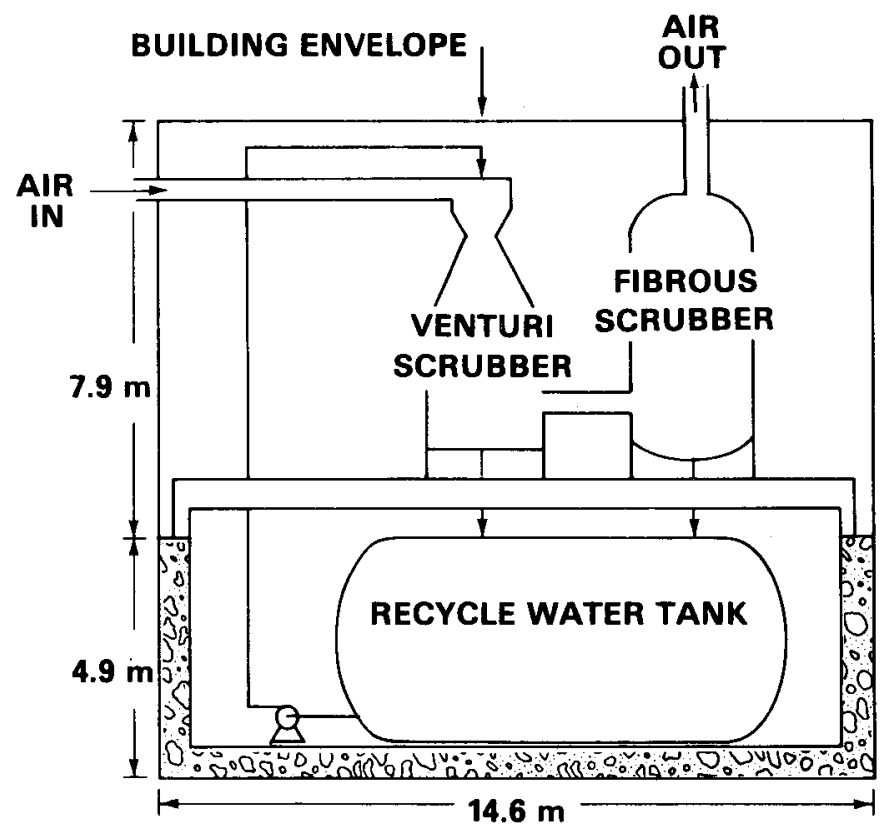

HEDL 7912-032.10

FIGURE 12. Layout of Venturi/Fibrous Scrubber - System HE-1. Neg 8009286-2 
TABLE 10

PARAMETERS FOR VENTURI/FIBROUS SCRUBBER - SYSTEM HE-1

$\begin{array}{ll}\text { Venturi Scrubber Flow Rate } & 1.70 \mathrm{~m}^{3} / \mathrm{min}(450 \mathrm{gal} / \mathrm{min}) \\ \text { Venturi Water Pressure Drop } & 0.55 \mathrm{MPa}(80 \mathrm{psid}) \\ \text { Venturi Throat Gas Velocity } & 16 \mathrm{~m} / \mathrm{s}(52 \mathrm{ft} / \mathrm{s}) \\ \text { Draft Generated By Venturi } & 248 \mathrm{~Pa}(1 \mathrm{in} \text {. Water) } \\ \text { Length of Fibrous Bed Elements } & 3.05 \mathrm{~m}(10 \mathrm{ft}) \\ \text { Diameter of Fibrous Bed Elements } & 0.79-\mathrm{m}(24-\mathrm{in} .) \text { 0D by 0.59-m (18-in.) ID } \\ \text { Number of Fibrous Elements } & \text { Four } \\ \text { Fiber Material } & \text { Polypropylene } \\ \text { Fibrous Element Spray Flow Rate } & 20.8 \mathrm{~cm}^{3} / \mathrm{s}(0.33 \mathrm{gal} / \mathrm{min}) \\ \text { Overall Particle Removal Efficiency } & 99 \% \\ \text { Volume of Recycle Water Tank } & 113.6 \mathrm{~m}^{3}(30,000 \mathrm{gal}) \\ \text { Relative Cost Units } & 1.0\end{array}$

\section{Submerged Grave1 Scrubber with Fibrous Backup - System HE-2}

This system combines the submerged gravel scrubber design of System LE-3 with the polypropylene fiber beds described for System HE-1. The combined system is shown conceptually in Figure 13 .

The gravel bed size used in this system is identical to that described for the $90 \%$ efficient System LE-3 (Table 8). The diameter of water tank and the water depth are the same as specified for System LE-3. The primary difference is the tank height required to accommodate the fibrous scrubber elements. Design parameters for the submerged gravel scrubber with fibrous back-up are listed in Table 11.

The submerged gravel bed with a fibrous backup is low in cost $(0.7$ relative units) in comparison with the other candidate scrubbers. When combined with passive features, e.g., no liquid pumping system requirement, this system appears to be a strong candidate. One off-setting aspect of this system is lack of a broad use-history. 


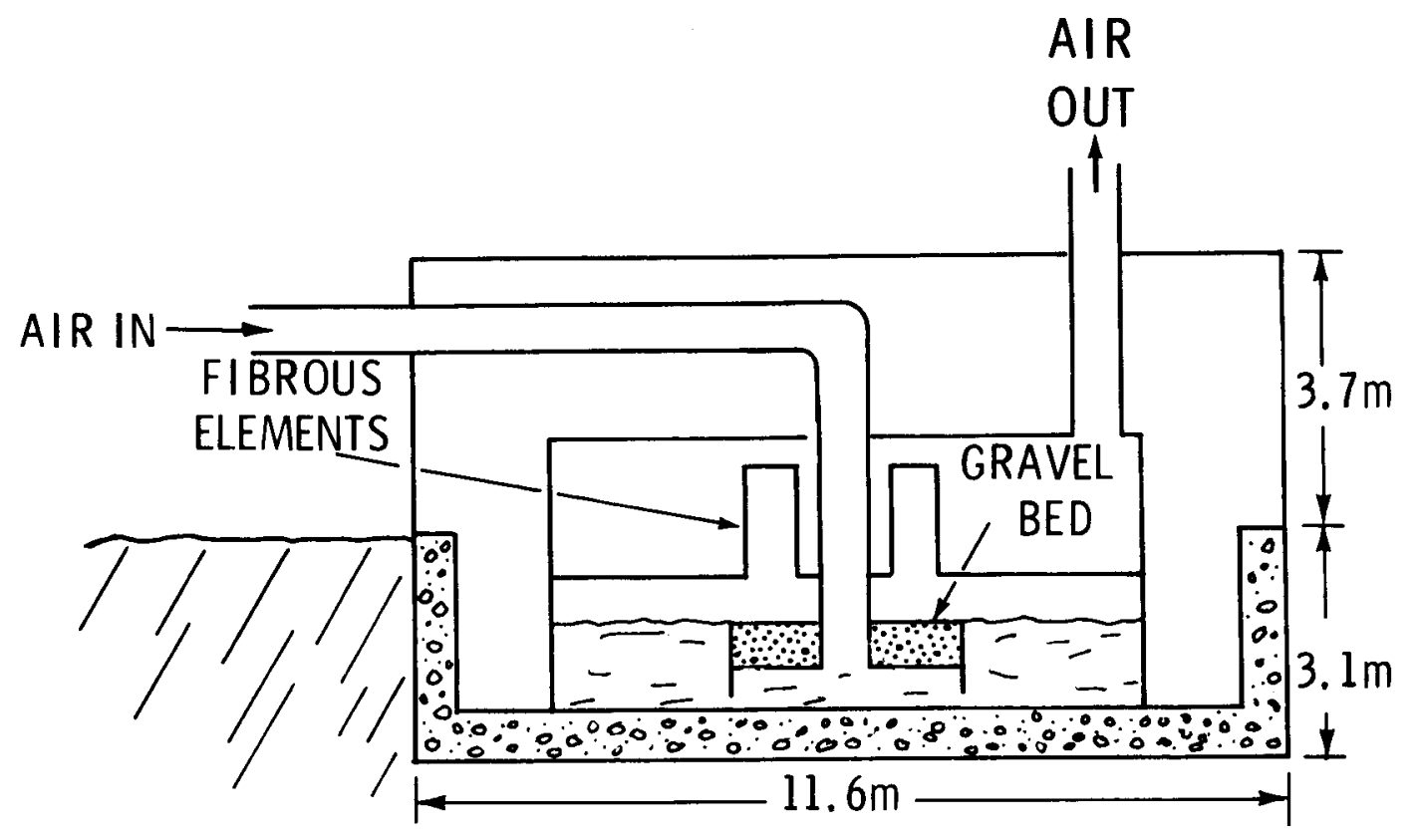

HEDL 7912-032.4

FIGURE 13. Layout of Submerged Gravel Scrubber with Fibrous Backup System HE-2. Neg 8009286-4

TABLE 11

PARAMETERS FOR SUBMERGED GRAVEL BED/FIBROUS SCRUBBER - SYSTEM HE-2

Scrubber Tank Overall Size

Gravel Bed Outside Diameter

Inlet Downcomer Diameter

Gravel Bed Depth

Superficial Gas Velocity

in Grave 1 ( $\max$ )

Crushed Rock Packing Size

Volume of Water

Fibrous Bed Elements Length

Fibrous Bed Elements Number

Fibrous Bed Elements Diameter

Fiber Material

Overall Particle Removal Efficiency

Relative Cost Units 7.9-m (26-ft) dia $\times 3.7-m(12-f t)$ height

$3.05 \mathrm{~m}(10 \mathrm{ft})$

$0.61 \mathrm{~m}(2 \mathrm{ft})$

$0.61 \mathrm{~m}(2 \mathrm{ft})$

$0.51 \mathrm{~m} / \mathrm{s}(100 \mathrm{ft} / \mathrm{min})$

9.5 to $13 \mathrm{~mm}$ ( $3 / 8$ to $1 / 2$ in.)

$51.1 \mathrm{~m}^{3}(13,500 \mathrm{gal})$

$1.22 \mathrm{~m}(4 \mathrm{ft})$

Ten

0.79-m (24-in.) OD $\times$ 0.59-m (18-in.) ID Polypropylene

$>99 \%$

0.70 


\section{Sand and Gravel Bed - System HE-3}

Sand and gravel bed filters rated high in a previous study ${ }^{(3)}$ because they are passive and can withstand high temperatures and corrosive atmospheres. A major drawback to sand filters is the low mass loading capability.

The sand bed design employed was based on an installation at the Savannah River Laboratory $(7)$ and loading capacity measurements made at HEDL for sodium compound aerosols. The holding capacity of a sand filter is tentatively estimated to be $1.0 \mathrm{~kg} / \mathrm{m}^{2}$ irrespective of air velocity. The superficial flow area required for the present application is

$$
5455 \mathrm{~kg} \times \frac{1 \mathrm{~m}^{2}}{\mathrm{~kg}}=5455 \mathrm{~m}^{2}
$$

If square, this unit would be $74 \mathrm{~m}(242 \mathrm{ft})$ on a side. This large bed would be difficult to locate close to the FFTF containment building.

A cross-sectional view of the sand and gravel layers is given in Figure 14 . As indicated $0.91 \mathrm{~m}(3 \mathrm{ft})$ of $\mathrm{fine}$ sand is supported by $0.46 \mathrm{~m}(1.5 \mathrm{ft})$ of coarser sand and $0.91 \mathrm{~m}(3 \mathrm{ft})$ of gravel, yielding a whole bed depth of $2.3 \mathrm{~m}(7.5 \mathrm{ft})$. An elevation view of the sand bed filter is presented in Figure 15.

Costs for the sand bed were taken from actual costs incurred at Savannah River Laboratory in 1973. The cost per unit area was increased to account for inflation and design change requirements to meet the $0.184 \mathrm{MPa}$ (12 psig) pressure rating. Parameters that describe the conceptual design of the sand filter are listed in Table 12.

The sand bed is much larger and much more costly than Systems HE-1 and HE-2. These considerations alone would appear to preclude the use of a sand bed filter for FFTF Margins. 


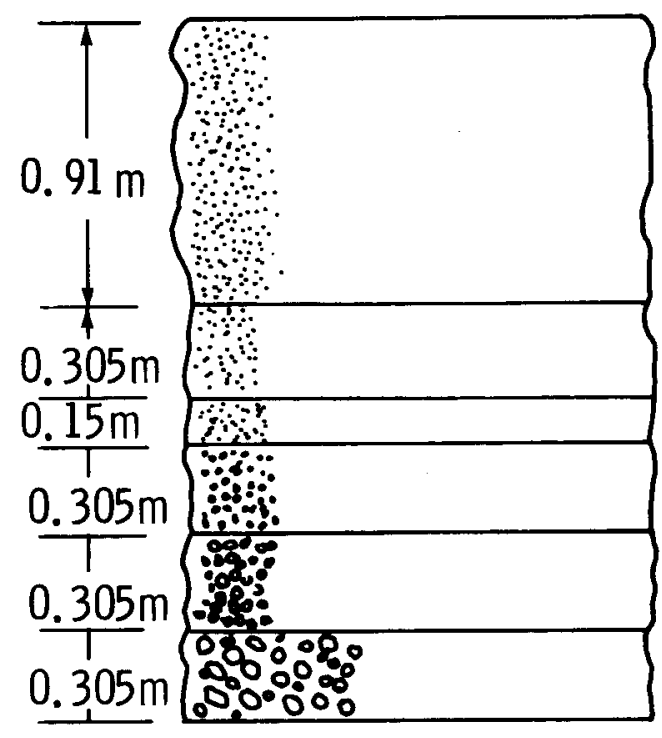

LAYER G, \#50 TO \#30 SAND

LAYER F, \#20 TO \#8 SAND

LAYER E, \#8 TO 1/4- in. SAND

LAYER C, 1/4-in. TO 5/8-in. GRAVEL

LAYER B, 5/8-in. TO 1-1/2-in. GRAVEL

LAYER A, 1-1/4-in. TO 3-in. GRAVEL

HEDL 7912-032.11

FIGURE 14. Aggregate Used in Sand Bed Filter - System HE-3 Neg 7913162-11

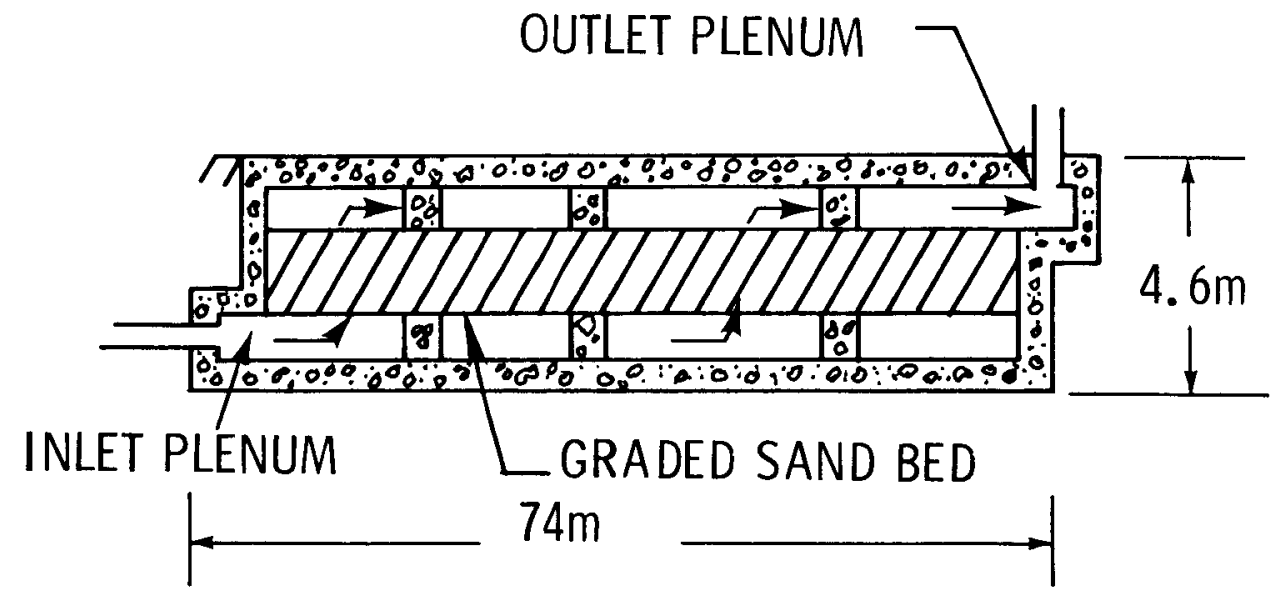

HEDL 7912-032.5

FIGURE 15. Layout of Sand and Gravel Bed - System HE-3. Neg 7913162-5 
TABLE 12

PARAMETERS FOR SAND AND GRAVEL BED - SYSTEM HE-3

Overall Bed Depth

Overall Height of Structure

Bed Planar Area

Aerosol Mass Captured ( $\mathrm{NaOH})$

Number of Layers of Aggregate

Largest Aggregate

Finest Aggregate

Basis For Aggregate Layer Design

Basis For Mass Loading Capacity

Removal Efficiency

Relative Cost
$2.3 \mathrm{~m}(7.5 \mathrm{ft})$

$4.6 \mathrm{~m}(15 \mathrm{ft})$

$5455 \mathrm{~m}^{2}\left(58,691 \mathrm{ft}^{2}\right)$

$5455 \mathrm{~kg}(12,000 \mathrm{lb})$

Six

31.8-m to $75.4-\mathrm{m}(1-1 / 2-$ in. to $3-$ in.) Grave 1

No. 50 to No. 30 Sand

SRL facility (Reference 7)

HEDL Data

$>99 \%$

16.0

\section{HEPA Filters - System HE-4}

HEPA filters rated for high temperature service would be installed in banks located inside a pressure building. The size and cost of this system relate directly to the number of individual filter units required.

Loading capacity of HEPA filters for sodium compound aerosols was studied by McCormack, et al. (8) It was found that the mass of aerosol required to plug a filter was a function of humidity. The minimum loading capacity was found to be $0.6 \mathrm{~kg}$ per standard HEPA unit. The number of HEPA units required is calculated:

$$
5455 \mathrm{~kg} \times \frac{1 \text { unit }}{0.6 \mathrm{~kg}}=9092 \text { units. }
$$

This number is very large, and if built, would represent the worlds largest HEPA filter installation. Therefore, no existing commercial HEPA filter banks could be used to cost and size this system. 
A conceptual design for this system was developed on the basis of the following premises:

- HEPA filters were used without prefilters.

- The filter units were arranged on horizontal plenums.

- A pressure building was used to house the filter banks.

The layout of the conceptual design is shown in Figure 16. As indicated, the required pressure building is large, approximating a truncated section of the reactor containment building itself. Parameters for this system are sumarized in Table 13.

The most notable data of Table 13 are the large size and high cost of the system. Compared to alternatives, this system would appear to be noncompetitive because of these two factors.

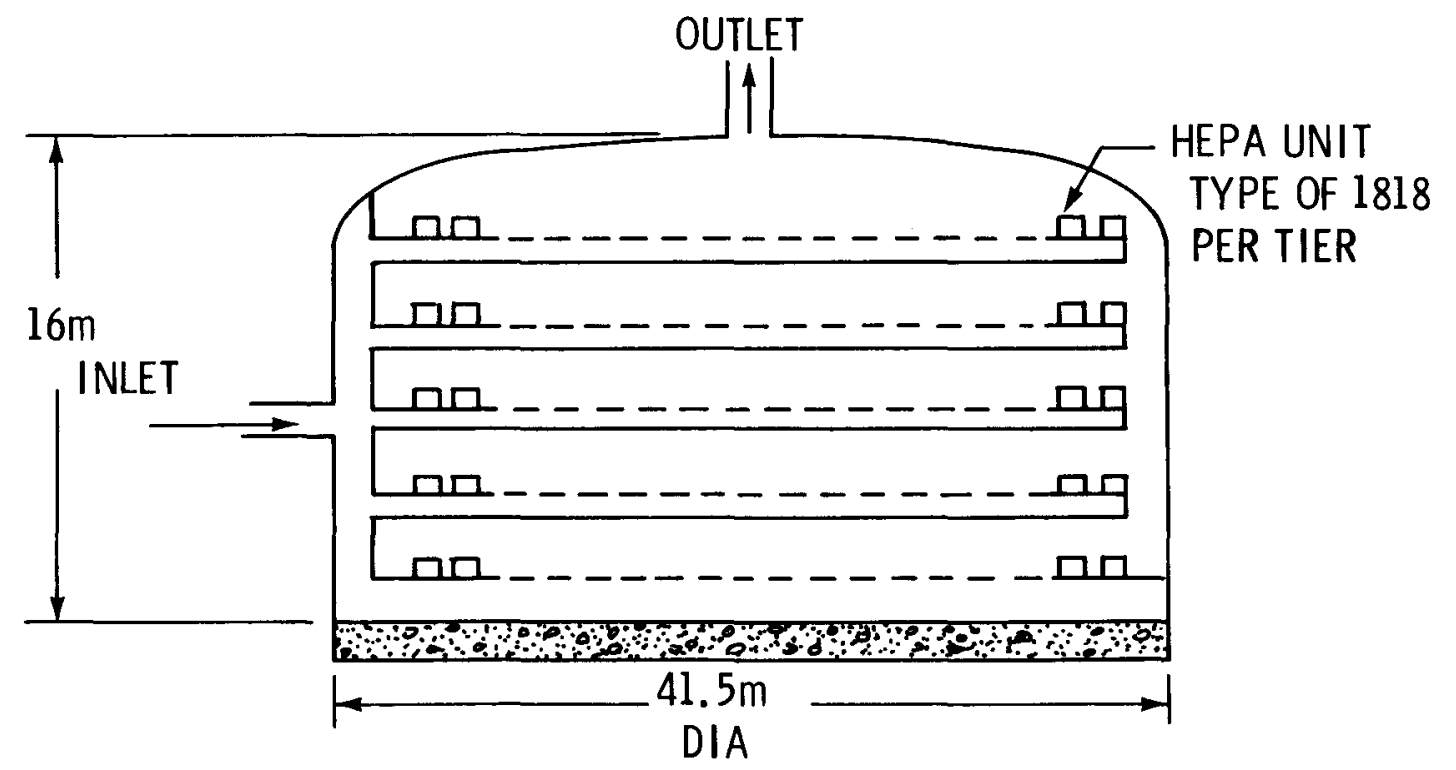

HEDL 7912-032.6

Figure 16. Layout for HEPA Filters - System HE-4. Neg 7913162-6 
TABLE 13

PARAMETERS FOR HEPA FILTERS - SYSTEM HE-4

$\begin{array}{ll}\text { Number of HEPA Filter Units Required } & 9090 \\ \text { Aerosol Mass Collected Per HEPA } & 0.6 \mathrm{~kg} \\ \text { HEPA Fil ter size } & 0.61 \mathrm{~m} \times 0.61 \mathrm{~m} \times 0.31 \mathrm{~m} \\ \text { HEPA Filter Temperature Rating } & 399^{\circ} \mathrm{C}\left(750^{\circ} \mathrm{F}\right) \\ \text { HEPA Filter Media Composition } & \text { Fiber Glass } \\ \text { No. of HEPA Units Per Tier } & 1818 \\ \text { No. of Tiers In Pressure Building } & 5 \\ \text { Diameter of Enclosure Building } & 41.5 \mathrm{~m}(136 \mathrm{ft}) \\ \text { Height of Enclosure Building } & 16 \mathrm{~m}(52.5 \mathrm{ft}) \\ \text { Particle Removal Efficiency } & >99 \% \\ \text { Relative Cost Units } & 110 \\ & \\ \text { C. COMPARISON OF ALTERNATIVE SYSTEMS } & \end{array}$

Candidate systems are ranked in terms of criteria described in Section V. The $90 \%$ efficient systems are ranked separately from the $99 \%$ efficient systems. Choice between the two classes of systems is left to the user who must determine whether the extra cost and complexity of the high efficiency system are justified by the incremental removal efficiency obtained.

\section{Ranking of $90 \%$ Efficient Candidates}

Numerical ranking of the three $90 \%$ efficient candidate systems is listed in Table 14. The rationale for assigning the individual scores is described in Appendix A.

From the total scores shown in Table 14, the candidates rank in the following order:

Submer ged Gravel Scrubber

Venturi Scrubber

Spray Chamber
(341 points)

(331.5 points)

(309 points) 
TABLE 14

NUMERICAL RATINGS OF 90\% EFFICIENT SYSTEMS

LE-1 LE-2

LE-3

Venturi Scrubber Submerged Gravel Spray Chamber

Weight Rating scor

Criterion Factor Rating

$1 a *$

$1 b^{*}$

$1 c^{*}$

$1 d$

3.5

4.0

4.0

Score

Rating

Score

Rating

Score

$2 a *$

$2 b \star$

$2 c^{*}$

$2 d$

$3 a *$

$3 b$

$4 a$

$4 b$ *

$4 c$

$4 d$

$4 e$

5
5
2
5

17.5

3.8

20.0

8.0

4.0

20.0

4.0

4.0

4.0

19.0

3.0

20.0

8.0

20.0

4.0

4.0

4.0

15.0

$3.5 \quad 31.5$

3.5

21.0

4.0

36.0

21.0

28.0

3.0

24.0

3.5

3.5

10.5

3.5

10.5

3.5
3.5

3.0

3.5

$4.0 \quad 16.0$

$4.0 \quad 16.0$

$3.0 \quad 15.0$

3.0

15.0

4.0

3.0

16.0

4.0

16.0

2.0

10.0

3.0

2.5

15.0

15.0

$4.0 \quad 12.0$

4.0

12.0

3.0

2.0

4.0

18.0

3.0

2.5

3.0

15.0

6.0

4.0

12.0

4.0

8.0

20.0

$5 \mathrm{a}$
$5 \mathrm{~b}$
$5 \mathrm{c}$
$5 \mathrm{~d}$

$2.5 \quad 7.5$

3.0

9.0

2.0

10.5

9.0

3.5

2.5

9.0

3.0

31.5

2.0

6.0

3.0

3.0

35.0
6.0

1.0
4.0

10.0

2.5
4.0

25.0

3.5

4.0

8.0

4.0

8.0

4.0

8.0

331.5

341.0

309.0

*Mandatory criterion: A rating of 2.0 or better is required to prevent automatic exclusion of concept. 
The submerged gravel bed ranks highest due to the favorable rating in reliability (Group 2) and ease of fabrication (Group 6). The weakest aspect of this system is technological credibility (Group 4). While there is little doubt that the system works as designed, lack of a use-history for the submerged gravel scrubber makes it less credible than the other two candidates. The performance of 1 arge scale tests on this system could enhance the credibility rating and make it even more desirable than the other candidates.

The venturi scrubber ranked second because the liquid recirculation system (pump \& piping) requirement resulted in lower ratings in reliability and cost (Groups 2 and 6, respectively). The broad industrial use-history resulted in the highest rating in technological credibility (Group 4 ).

The spray chamber ranked last. It is quite similar in many respects to the venturi scrubber, but the large size and attendant high cost make it less desirable. No factors were uncovered that override the low numerical score for the spray chamber and it was eliminated from the viable candidate list.

The two prime candidates had numerically similar scores. Also, it is evident that both system designs are feasible for the FFTF containment margins application. Therefore, a final selection between the submerged gravel scrubber and the venturi scrubber should be based on trade-off studies beyond the scope of this report.

\section{Ranking of $99 \%$ Efficient Candidates}

The numerical ranking of the four 99\% efficient systems is listed in Table 15. The rationale for assigning the individual scores is described in Appendix $B$. From the total scores shown in Table 15, the candidates rank in the following order:

Submerged Gravel/Fibrous Scrubber Venturi/Fibrous Scrubber

Sand and Grave 1 Bed

HEPA Filter Bank
(338.1 points)

(335.9 points)

(282.9 points)

(257.7 points) 
TABLE 15

NUMERICAL RATINGS OF $99 \%$ EFFICIENT SYSTEMS

\begin{tabular}{|c|c|c|c|c|c|c|c|c|c|}
\hline \multirow[b]{2}{*}{ Criterion } & \multirow{2}{*}{$\begin{array}{l}\text { Weight } \\
\text { Factor } \\
\end{array}$} & \multicolumn{2}{|c|}{$\begin{array}{c}\text { HE-1 } \\
\text { Venturi-Fibrous } \\
\end{array}$} & \multicolumn{2}{|c|}{$\begin{array}{c}\text { HE-2 } \\
\text { SGS-Fibrous } \\
\end{array}$} & \multicolumn{2}{|c|}{$\begin{array}{c}\mathrm{HE}-3 \\
\text { Sandbed } \\
\end{array}$} & \multicolumn{2}{|c|}{$\begin{array}{c}\text { HE-4 } \\
\text { HEPA Filters }\end{array}$} \\
\hline & & Rating & Score & Rating & Score & Rating & Score & Rating & Score \\
\hline $\begin{array}{l}1 a^{\star} \\
1 b^{\star} \\
1 c^{\star} \\
1 d\end{array}$ & $\begin{array}{l}5 \\
5 \\
2 \\
5\end{array}$ & $\begin{array}{l}4.0 \\
3.5 \\
3.0 \\
4.0\end{array}$ & $\begin{array}{r}20.0 \\
17.5 \\
6.0 \\
20.0\end{array}$ & $\begin{array}{l}4.0 \\
3.5 \\
3.3 \\
4.0\end{array}$ & $\begin{array}{r}20.0 \\
17.0 \\
6.6 \\
20.0\end{array}$ & $\begin{array}{l}3.0 \\
3.0 \\
4.0 \\
2.0\end{array}$ & $\begin{array}{r}15.0 \\
15.0 \\
8.0 \\
10.0\end{array}$ & $\begin{array}{l}4.0 \\
2.5 \\
3.6 \\
2.0\end{array}$ & $\begin{array}{r}16.0 \\
12.0 \\
7.2 \\
10.0\end{array}$ \\
\hline $\begin{array}{l}2 a^{\star} \\
2 b^{\star} \\
2 c^{\star} \\
2 d^{*}\end{array}$ & $\begin{array}{l}9 \\
6 \\
8 \\
3\end{array}$ & $\begin{array}{l}3.0 \\
3.5 \\
3.0 \\
3.5\end{array}$ & $\begin{array}{l}27.0 \\
21.0 \\
24.0 \\
10.5\end{array}$ & $\begin{array}{l}3.5 \\
3.5 \\
3.5 \\
3.4\end{array}$ & $\begin{array}{l}31.5 \\
21.0 \\
28.0 \\
10.2\end{array}$ & $\begin{array}{l}4.0 \\
4.0 \\
3.8 \\
2.0\end{array}$ & $\begin{array}{r}36.0 \\
24.0 \\
30.4 \\
6.0\end{array}$ & $\begin{array}{l}4.0 \\
4.0 \\
2.0 \\
1.0\end{array}$ & $\begin{array}{r}36.0 \\
24.0 \\
16.0 \\
3.0\end{array}$ \\
\hline $\begin{array}{l}3 a^{*} \\
3 b\end{array}$ & $\begin{array}{l}4 \\
5\end{array}$ & $\begin{array}{l}3.6 \\
3.0\end{array}$ & $\begin{array}{l}14.4 \\
15.0\end{array}$ & $\begin{array}{l}3.8 \\
3.0\end{array}$ & $\begin{array}{l}15.2 \\
15.0\end{array}$ & $\begin{array}{l}4.0 \\
0.0\end{array}$ & $\begin{array}{r}16.0 \\
0.0\end{array}$ & $\begin{array}{l}4.0 \\
0.0\end{array}$ & $\begin{array}{r}16.0 \\
0.0\end{array}$ \\
\hline $\begin{array}{l}4 a \\
4 b^{\star} \\
4 c \\
4 d \\
4 e\end{array}$ & $\begin{array}{l}5 \\
6 \\
5 \\
3 \\
3\end{array}$ & $\begin{array}{l}4.0 \\
3.0 \\
3.0 \\
4.0 \\
4.0\end{array}$ & $\begin{array}{l}20.0 \\
18.0 \\
15.0 \\
12.0 \\
12.0\end{array}$ & $\begin{array}{l}2.0 \\
3.1 \\
3.0 \\
2.0 \\
3.0\end{array}$ & $\begin{array}{r}10.0 \\
18.6 \\
15.0 \\
6.0 \\
9.0\end{array}$ & $\begin{array}{l}3.0 \\
4.0 \\
2.0 \\
3.5 \\
2.5\end{array}$ & $\begin{array}{r}15.0 \\
24.0 \\
10.0 \\
10.5 \\
7.5\end{array}$ & $\begin{array}{l}3.8 \\
4.0 \\
2.0 \\
3.0 \\
3.5\end{array}$ & $\begin{array}{r}19.0 \\
24.0 \\
10.0 \\
9.0 \\
10.5\end{array}$ \\
\hline $\begin{array}{l}5 a \\
5 b \\
5 c \\
5 d\end{array}$ & $\begin{array}{l}3 \\
3 \\
3 \\
3\end{array}$ & $\begin{array}{l}4.0 \\
3.5 \\
2.0 \\
3.0\end{array}$ & $\begin{array}{r}12.0 \\
10.5 \\
6.0 \\
9.0\end{array}$ & $\begin{array}{l}4.0 \\
3.5 \\
3.0 \\
3.0\end{array}$ & $\begin{array}{r}12.0 \\
10.5 \\
9.0 \\
9.0\end{array}$ & $\begin{array}{l}3.0 \\
3.0 \\
3.5 \\
2.0\end{array}$ & $\begin{array}{r}9.0 \\
9.0 \\
10.5 \\
6.0\end{array}$ & $\begin{array}{l}4.0 \\
2.0 \\
3.5 \\
0.0\end{array}$ & $\begin{array}{r}12.0 \\
6.0 \\
10.5 \\
0.0\end{array}$ \\
\hline $\begin{array}{l}6 a \\
6 b \\
6 c\end{array}$ & $\begin{array}{r}10 \\
2 \\
2 \\
\end{array}$ & $\begin{array}{l}3.0 \\
4.0 \\
4.0\end{array}$ & $\begin{array}{r}30.0 \\
8.0 \\
8.0 \\
\end{array}$ & $\begin{array}{l}4.0 \\
3.0 \\
4.0\end{array}$ & $\begin{array}{r}40.0 \\
6.0 \\
8.0 \\
\end{array}$ & $\begin{array}{l}1.0 \\
3.5 \\
2.0\end{array}$ & $\begin{array}{r}10.0 \\
7.0 \\
4.0 \\
\end{array}$ & $\begin{array}{l}0.0 \\
4.0 \\
4.0\end{array}$ & $\begin{array}{l}0.0 \\
8.0 \\
8.0 \\
\end{array}$ \\
\hline Total & 100 & & 335.9 & & 338.1 & & 282.9 & & 257.7 \\
\hline
\end{tabular}

*Mandatory criterion: A rating of 2.0 or better is required to prevent automatic exclusion of concept. 
The 1 ow ratings of the sand and gravel bed and HEPA filter systems, as well as their very high costs and large sizes, eliminated these two systems from further consideration.

The two scrubber systems have comparable scores. The submerged grave1/fibrous scrubber was rated low in technological credibility (Group 4) because it lacks an extensive use-history. In all other categories the submerged gravel scrubber rated superior to the venturi system.

In selecting between the two scrubber systems, the main trade-off is an element of risk in scale-up of the submerged gravel unit versus greater cost and mechancial complexity of the venturi system. Final selection should be made by the system designer following conceptual design studies.

\section{ASSESSMENT OF FEASIBILITY OF AIR CLEANING SYSTEMS FOR FFTF CONTAINMENT} MARGINS APPLICATIONS

A review of available information concludes that air cleaning based on aqueous scrubbers is feasible for the FFTF Containment Margins application. Wet systems (scrubbers) are preferred compared to dry systems because the high aerosol mass loading requirements result in very large and costly systems for all dry systems considered.

Extensive testing of scrubber systems at large scale and under realistic aerosol stream conditions has demonstrated the efficient and reliable operation of the candidates. While the design efficiency of the two stage systems was stated as $99 \%$ in this study, more detailed analyses (9) and experiments $(5)$ have shown the removal efficiencies to exceed $99.9 \%$. 


\section{REFERENCES}

1. S. F. Bankert, et al., Containment Margins in FFTF for Postulated Failure of In-Vessel Post-Accident Heat Removal, HEDL-TME 77-18, Hanford Engineering Development Laboratory, Richland, WA, April 1977.

2. Code of Federal Regulations, Title 10, Part 100, (cited in text as 10 CFR 100).

3. R.K. Hilliard, J.D. McCormack and A.K. Postma, Evaluation of Air Cleaning System Concepts for Emergency Use in LMFBR Plants, HEDL-TME 76-41, Hanford Engineering Development Laboratory, Rich 1 and WA, December, 1976.

4. J.D. McCormack, A.K. Postma and J.A. Schur, Water Evolution From Heated Concrete, HEDL-TME 78-87, Hanford Engineering Development Laboratory, Richland, WA, February, 1979.

5. R.K. Hilliard, et al., "Containment Air Cleaning For LMFBRs," in Proceedings of the International Meeting on Fast Reactor Safety Technology, SeattTe, WA, August 19-23, 1979 Vol. II, p. 842.

6. S. Calvert, et al., Scrubber Handbook, Vol I, "Wet Scrubber System Study," PB213-016, Prepared for the U.S. Environmental Protection Agency by Ambient Purification Technology, Riverside, CA, July, 1972.

7. R.A. Moyer, J.H. Crawford and R.E. Tatum, "Deep-Bed Sand Filter at Savannah River Laboratory," Proceedings of the 13th DOE Nuclear Air Cleaning Conference, CONF-740807, San Francisco, CA, pp. 632-640, August 12-15, 1974.

8. J.D. McCormack, R.K. Hilliard and J.R. Barreca, "Loading Capacity of Various Filters For Sodium 0xide/Hydroxide Aerosols," Proceedings of the 15 th DOE Nuclear Air Cleaning Conference, CONF-780819, Boston, MA, pp 1018-1043, August 7-10, 1978.

9. A.K Postma and R.K. Hilliard, Nucleation and Capture of Condensible Airborne Contaminants in an Aqueous Scrubbing System, HEDL-TME 78-82, Hanford Engineering Development Laboratory, Richland, WA, September 1978. 
A P P ENDIX A

NUMER ICAL RANKING OF 90\% EFFICIENT SYSTEMS

A-1 
Three candidates (an eductor venturi, a spray chamber and a sumberged gravel bed) are compared on a criterion-by-criterion basis. As noted in Section $V$, the numerical scores varied from 0 to 4.0 . A rating of 4.0 denotes totally acceptable conformance and a rating of 0.0 denotes totally unacceptable conformance.

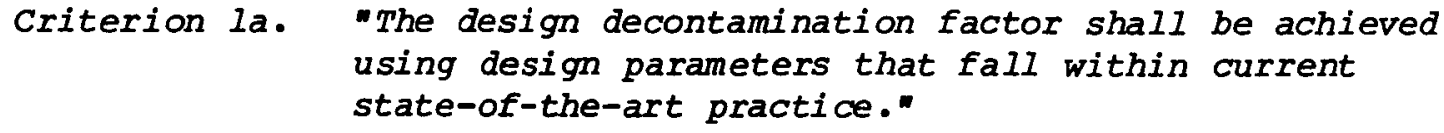

For this criterion scores were assigned on the basis of the inherent removal efficiency. The submerged gravel scrubber was rated 3.8. Average removal efficiencies exceeded $99 \%$ for a bed design comparable to that developed in this study. This indicates a design removal efficiency of $90 \%$ could be met without difficulty.

The venturi scrubber rated 3.5 because Containment Systems Test Facility (CSTF) tests on a $1000 \mathrm{cfm}$ prototype showed that removal efficiencies exceeding $90 \%$ could be obtained routinely. (5)

The spray chamber rated 3.0. Calculations and experiments in CSTF show efficiencies of $90 \%$ can be otained, but carefully defined operating parameters must be adhered to. The spray chamber is inherently less efficient that the other two scrubbers but is satisfactory for the present application.

Criterion 1b. "The system shall handle dry or sticky particles and particles of varying chemical composition."

All three systems rate 4.0 because the physical and chemical composition of the aerosol does not adversely affect performance.

Criterion 1C. "System effectiveness shall not be degraded by the radiation dose caused by the accident over the required operating period." 
A11 three systems are rated 4.0 because they use materials and components that could be constructed to easily withstand the radiation exposures encountered.

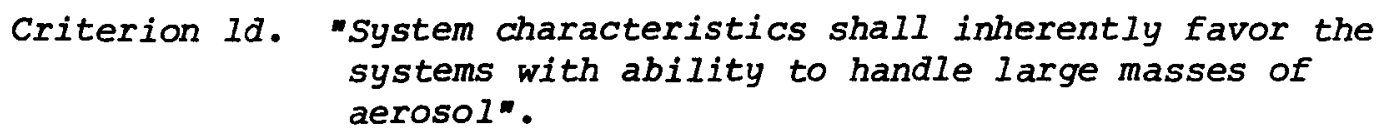

The three systems are equally efficient in handling large masses of sodium compound aerosols. Each was assigned a score of 4.0 .

$$
\begin{array}{r}
\text { Criterion 2a. "The air cleaning system shall have a high proba- } \\
\text { bility of startup after initiation of the accident". }
\end{array}
$$

A11 three systems are equally dependent on a supply of water and on the operation of valves in the vent line. The submerged gravel bed has no active liquid pumping system and was rated 4.0 because it employs no pumps. The other two scrubbers were rated 3.5 because they employ pumps.

\section{Criterion $2 b$. "The system shall not degrade during periods of non-use".}

Because all three systems are expected to be "dry" in standby, little degradation would occur during non-use. If rusting of steel does occur, it will affect the venturi and spray chamber because they employ small openings in spray nozzles. On the other hand, biological growths in the gravel bed represent a possible mode of degradation not present in the other two systems. Overall, the systems appear to be equivalent and were assisgned a 3.5 rating.

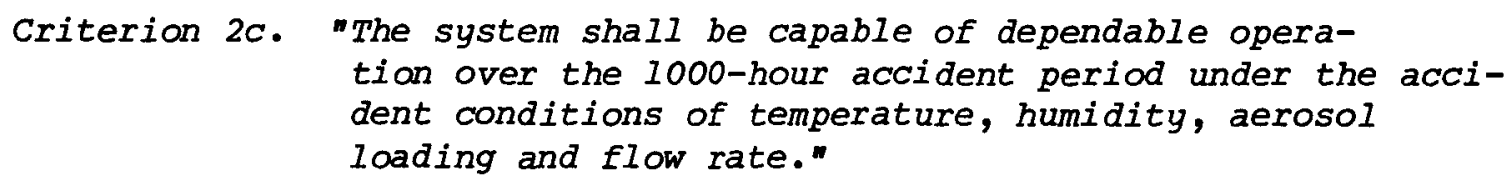

For this criterion, scores were assigned on the basis of passivity and the ability to handle changing thermal and flow conditions. All three systems 
will require a water source to replace evaporative losses, A system requiring no service during an accident would be more reliable. Because the venturi and spray scrubbers require electrical energy and operation of water pumps, they were assigned scores of 3.0. The submerged gravel scrubber does not employ a liquid pumping system and was rated 3.5 .

\section{Criterion 2d. "The system shall require simple components and control and conservative design stresses.}

The gravel bed is probably the most complex component of the three candidate systems. However, the spray and venturi systems require control systems for liquid pumping. None of the three systems imposes design stress problems. Therefore, the advantages and disadvantages are off-setting and a 11 three systems were assigned scores of 3.5 .

\section{Criterion 3a. "Inadvertent operation of the system shall not harm the containment system (containment vessel and purge system) or constitute a hazard to personnel.}

All three candidate systems are external to the containment vessel and involve no hazard to personnel. No detrimental impacts from inadvertent operation of the system could be identified and all systems were assigned a score of 4.0 .

\section{Criterion $3 b$. "The size of the system shall be compatible with instal- lation adjacent to the Reactor Containment Building $(R C B)$, and not significantly impact the location of other ancillary plant systems."}

Foot print sizes for the three candidates are comparable and small enough to be located adjacent to the RBC. All systems were rated 3.0 recognizing that an even smaller system would be more desirable.

\footnotetext{
Criterion 4a. "The air cleaning concept is based on highly developed technology."
} 
The eductor venturi scrubber system is widely used in industry and was rated 4.0. The spray chamber was rated 3.0 because spray air washers are widely used but not typically designed for efficiencies as high as this application requires. The submerged gravel scrubber was rated 2.0 because, al though many studies of particle capture in a massive packing bed are published, a self-cleaning bed is novel and not yet supported by industrial practice.

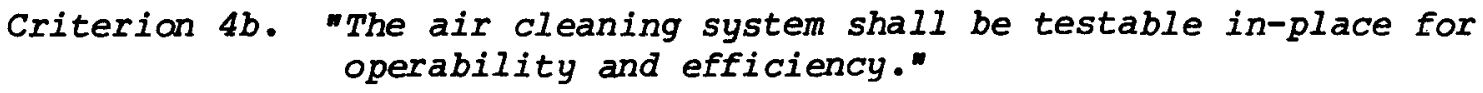

Perodic testing of the aqueous systems involve the following:

1. Fill tank with water

2. Start pumps (venturi and spray)

3. Start fans

4. Inject test particles

5. Collect aerosol samples

6. Measure liquid and gas flow rates

7. Shut down fans and pumps

8. Drain water from system

Because this procedure is more complex than the required procedure for a dry filter system the simpler system (the submerged gravel scrubber) was assigned a score of 3.0. The venturi and spray scrubbers were rated at 2.5 because additional effort is required to operate the liquid pumps and put them into standby condition.

Criterion 4c. "The system performance shall be predictable by verified mathematical models."

Models for predicting particle removal exist for all three candidates. Reasonable agreement between theory and experiment is evident in available comparisons, and a rating of 3.0 was assigned to all candidates.

Criterion 4d. "The equipment scale-up from currently available sizes to FFTF plant application shall be small." 
Both the venturi and spray scrubbers are used industrially in sizes larger than required for the application; therefore, no scale-up is required and a score of 4.0 is assigned.

The submerged gravel scrubber would require a scale-up in diameter by a factor of three as compared to engineering scale units operating to date. A rating of 2.0 is assigned because of the scale-up.

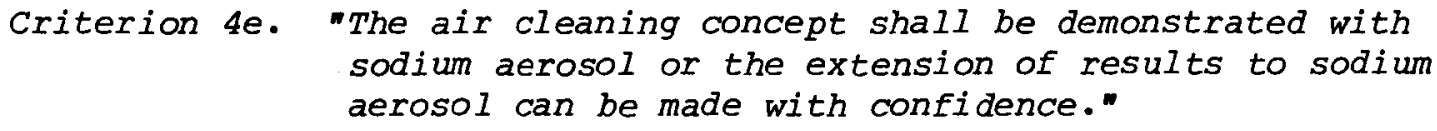
sodium aerosol or the extension of results to sodium aerosol can be made with confidence."

A11 three system concepts have been extensively tested at HEDL with sodium compound aerosols and a 4.0 score is assigned.

Criterion 5a. "The air cleaning concept shall be effective for the
entire particle size spectrum during the accident."

All three systems are expected to show moderate to low efficiencies for submicron particles. Ranking was based on the measured sodium compound particle efficiency of each system. The submerged gravel scrubber rated 3.0 , the venturi 2.5 and the spray scrubber 2.0 .

Criterion $5 \mathrm{~b}$. "The system performance shall not be highly senstive to the atmospheric temperature or relative humidity."

A11 three systems process gas at any temperature within design limits and operation is independent of the relative humidity of inlet gas. Since water would have to be added to compensate for evaporation, all systems were rated 3.5 .

Criterion 5c. "The system energy consumption shall be low."

Energy requirements for the three candidates are modest. Scores were assigned on the basis of horsepower requirements for the conceptual designs, allowing for a possible purge $f$ an operation. Because the gravel scrubber 
has no water pump, it was rated 3.0. The spray chamber was rated 2.5 and the venturi scrubber 2.0 .

Criterion 5d. "Post-accident recovery shall be facilitated by the air cleaning system."

Contaminants removed from the air stream would be dissolved or entrained in the water of all three systems. After an accident, this water could be processed to put the contaminants into the desired form. This ability is considered satisfactory and a score of 3.0 is assigned to all three systems.

Criterion 6a. "System costs, capital and maintenance, shall be low." Scores were assigned on the basis of captial costs estimated from the conceptual designs developed. The relative costs and ratings are as follows:

\section{$\underline{\text { System }} \quad$ Relative Cost Units $\quad \underline{\text { Score }}$}

$\begin{array}{lll}\text { Eductor Venturi } & 0.80 & 2.5 \\ \text { Submerged Gravel } & 0.45 & 3.5 \\ \text { Spray Chamber } & 1.6 & 1.0\end{array}$

Criterion 6b. "Materials and techniques used in construction shall be readily available."

All three systems use standard construction materials. The ventur $i$ and spray chamber scrubbers use standard construction techniques and were rated 4.0. Since the submerged gravel bed represents a small departure from usual construction techniques, it was given a score of 3.0 .

Criterion 6c. "Components and equipment shall be readily available."

All three systems use standard, readily available components and were assigned a score of 4.0 . 
A P P E D I X B

NUMER ICAL RANKING OF 99\% EFFICIENT SYSTEMS

B-1 
The four candidates (an eductor venturi with fibrous scrubber, a submerged gravel bed with fibrous scrubber, sand and gravel bed and a HEPA filter system) are compared on a criterion-by-criterion basis. As noted in Section $V$, the numerical scores varied from 0.0 to 4.0 . A rating of 4.0 denotes acceptable conformance and a rating of 0.0 denotes totally unacceptable conformance.

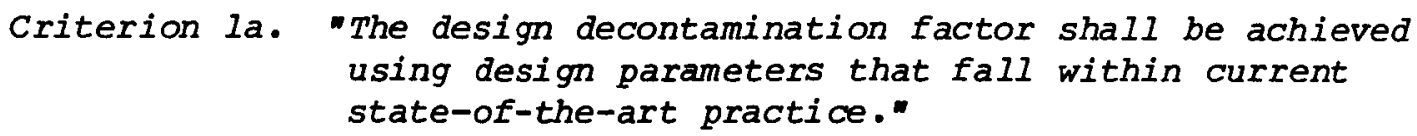

While all four candidates exhibit efficiencies that exceed the $99 \%$ design level, the two scrubber systems and the HEPA filter system are appreciably more efficient than the sand filter. Therefore, the two scrubber systems and the HEPA filter system were assigned scores of 4.0 and the sand and gravel filter was assigned a score of 3.0 .

Criterion 1b. "The system shall handle dry or sticky particles and particles of varying chemical composition."

The two scrubber candidates are minimally affected by particle chemical composition because solubility considerations dictate minimum water volumes and the dissolution of aerosol trapped in the fibrous elements. A score of 3.5 was assigned to both scrubbers.

The physical characteristics of particles (sticky or dry) appreciably affect the mass loading capability of the sand bed and HEPA filter systems because fiberglass is susceptible to corrosion by moist sodium hydroxide. The sand bed was given a rating of 3.0. The HEPA filter system was rated 2.5 .

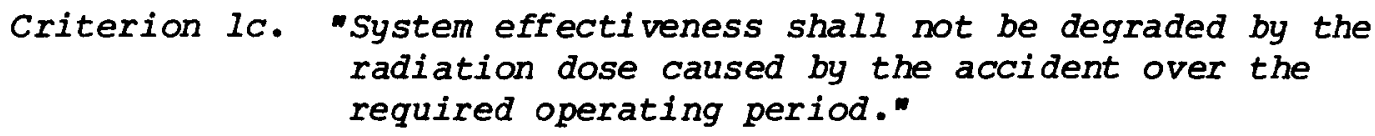

Al1 four candidates can be designed to accommodate the modest radiation exposures expected. Due to the difference in inherent resistance to radiation 
doses, the sandbed filter was rated 4.0, the HEPA filter system 3.6, the submerged gravel scrubber 3.3 and the venturi scrubber 3.0 . The submerged gravel scrubber uses polypropylene fibers that are susceptible to radiation damage, although the radiation doses expected for this application do not cause material failures. In addition to the use of polypropylene, the venturi uses pumps and motors not present in the other systems.

Criterion 1d. "System characteristics shall inherently favor systems with ability to handle large masses of aerosol".

Because scrubber candidates are able to capture large masses of aerosol without difficulty, they were rated 4.0. Both the sand bed and HEPA systems are inherently inefficient in trapping 1 arge aerosol masses. The two dry systems were rated 2.0 .

\section{Criterion 2a. "The system shall have a high probability of start-up} after initiation of the accident."

The two dry scrubbers are rated 4.0 because there are no active components for venting and because no water pools are maintained during the systems shelf life.

The two scrubbers (venturi and submerged gravel bed) require water and introduce a failure mode not present in the dry systems. The venturi scrubber also requires liquid pump start-up. Therefore, the submerged gravel and venturi scrubbers were rated at 3.5 and 3.0 respectively.

Criterion $2 b$. "The system shall not degrade during periods of non-use."

Both dry systems were rated 4.0 because no credible degradation mode could be identified during periods of non-use. The scrubbers were rated 3.5 because of possible corrosion in the water storage tank.

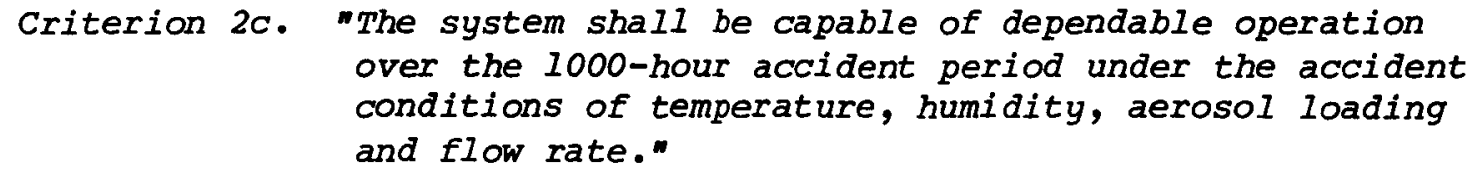
over the 1000-hour accident period under the accident conditions of temperature, humidity, aerosol loading and flow rate." 
Scores were assigned to reflect inherent aspects of reliability in each system. The factors and scores are summarized as follows:

TABLE B-1

SYSTEM RELIABILITY RATINGS

\begin{tabular}{|c|c|c|}
\hline System & Score & Judgment Factors \\
\hline Sand Bed (HE-3) & 3.8 & $\begin{array}{l}\text { No water required, no } \\
\text { pumps }\end{array}$ \\
\hline Submerged Grave $(\mathrm{HE}-2$ ) & 3.5 & No pump required \\
\hline Venturi/Fibrous (HE- 1 ) & 3.0 & Pump required \\
\hline HEPA Filters (HE-4) & 2.0 & $\begin{array}{l}\text { Possible corrosion } \\
\text { of media by } \mathrm{NaOH}\end{array}$ \\
\hline
\end{tabular}

Criterion 2d. "The system shall require simple components and control and conservative design stresses."

All four candidate systems incorporate simple components but differ in overall design. System scores and judgment factors are summarized as follows:

TABLE B-2

SYSTEM DESIGN RATINGS

$\begin{array}{lcl}\begin{array}{c}\text { System } \\ \text { Venturi/Fibrous (HE-1) }\end{array} & \text { Score } & \begin{array}{l}\text { Judgment Factors } \\ \text { Standard design, modest } \\ \text { size }\end{array} \\ \text { Submerged Gravel (HE-2) } & 3.5 & \begin{array}{l}\text { Modest size, novel } \\ \text { gravel bed }\end{array} \\ \text { Sand bed (HE-3) } & 2.0 & \begin{array}{l}\text { Very large bed, under } \\ \text { pressure }\end{array} \\ \text { HEPA Filter (HE-4) } & 1.0 & \begin{array}{l}\text { Largest pressurized } \\ \text { HEPA installation in } \\ \text { the world }\end{array}\end{array}$


Criterion 3a. "Inadvertent operation of the air cleaning system shall not harm the containment system or constitute a hazard to peronnel."

Because all four candidate systems are external to the containment vessel and could not harm personnel, no major short-comings for any of the systems are envisioned. Both dry systems were rated 4.0. Because effort is required to drain tanks and lines, the submerged gravel and venturi scrubbers were rated 3.8 and 3.6 , respectively.

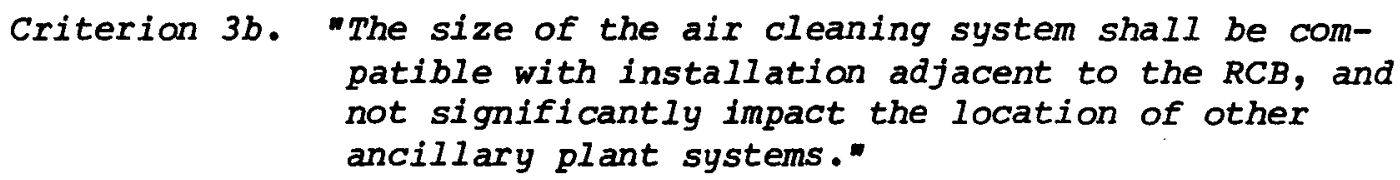

The two scrubbers are of similar size and appear to fit within available free regions close to the containment vessel. They were given a rating of 3.0. Because dry systems are very large, cannot be located adjacent to the containment vessel and would grossly impact the location of ancillary plant systems, they were assigned scores of 0.0 .

Criterion 4a. "The air cleaning concept shall be based on highly developed technology."

The venturi/fibrous system uses components that have broad industrial application. The combined system was tested extensively at HEDL with sodium compound aerosols typical of those postulated for margins application. (5) Therefore, this system was rated 4.0 .

The HEPA filter system was rated 3.8. Although HEPA filters have very broad industrial application, questionable use with $\mathrm{NaOH}$ aerosol and the large installation size detracted from the score. The sand bed rated 3.0 because $f$ ew sand bed filters are used in industry. The submerged gravel scrubber was rated 2.0 because the system was not demonstrated at full scale.

Criterion 4b. "The air cleaning system shall be testable in-place for operability and efficiency." 
A11 systems are external to the containment building and could be tested without significantly impacting other plant operations. However, the scrubber systems would require more effort to operate and put into standby condition. Both the HEPA and sand bed filter systems were assigned scores of 4.0 because the testing procedure would involve only the operation of valves, $f$ ans and aerosol testing instruments. The venturi/fibrous scrubber was rated 3.0. The submerged gravel scrubber was rated slightly higher at 3.1 because it has no liquid pumping system to operate.

Criterion 4c. "The system's performance shall be predictable by verified mathematical models."

For the scrubbers, particle capture, heat transfer and mass loading capacity can be predicted by available models. Although the models are probably satisfactory, additional verification work would increase confidence. Therefore the scrubbers were rated 3.0.

Ory systems performance, particularly the mass loading capacity, lacks extensive modeling. Off-setting lack of modeling is the availability of empirical information that can be used to design the dry systems. A score of 2.0 was assigned to both the sand bed and HEPA filter systems.

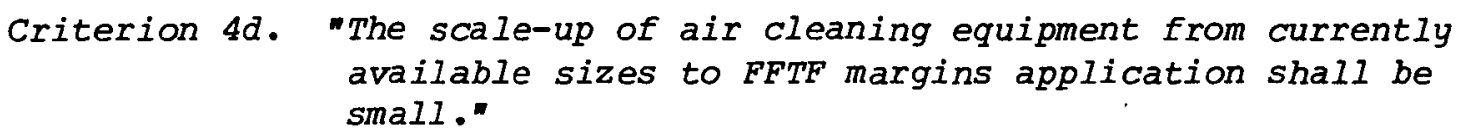
available sizes to FFTF margins application shall be small."

The venturi/fibrous scrubber was rated 4.0 because no scale-up in size is involved. The sand bed rated 3.5 because, al though the required unit would be 1 arger than any presently in existence, there appear to be no technical issues involved in enlarging the planar area. The HEPA filter installation was rated 3.0. While there is no scale-up of the individual filter units, the assembled system would be 1 arger than any existing installation. The submerged gravel/fibrous scrubber was rated 2.0 because a 1 arge system was not tested and requires scale-up. 
Criterion 4e. "The system concept shall have been demonstrated with sodium compound aerosol or the extension of results to sodium aerosol can be made with confidence."

A11 four candidates were tested with sodium compound aerosols at HEDL and at other laboratories. The venturi/fibrous scrubber rated 4.0. Extensive tests at HEDL have demonstrated the efficiency of this system. The HEPA filter system rated 3.5. Significant experience on trapping sodium compound aerosols was accrued in HEDL test programs. The submerged gravel/fibrous scrubber rated 3.0 because the equipment used in HEDL tests was of a modest size. The sand bed filter rated 2.5 because less information is available on this candidate than for the other candidates.

Criterion 5a. "The air cleaning system shall be effective for the

The two scrubber systems and the HEPA filter system trap all particles sizes efficiently and rate 4.0. HEDL experiments show that a measurable fraction of fine particles can penetrate a sand bed filter, and this candidate was rated 3.0 .

\section{Criterion 5b. "The system performance shall not be highly sensi- tive to the atmospheric temperature or relative humidity."}

The two scrubber systems rated 3.5 because their performance is independent of relative humidity and affected by temperature only under extreme conditions when water temperatures approach the safe limit for polypropylene fibers. The sand bed filter was rated 3.0 because loading capacity is dependent on particle stickiness, which in turn depends on relative humidity. The HEPA filter system was rated 2.0 because its loading capacity is dependent on relative humidity and the fiber glass medium is susceptible to corrosion by moist $\mathrm{NaOH}$.

Criterion 5c. "The system energy consumption shall be low." 
The sand and HEPA filter systems rated 3.5 because they would exhibit low pressure drop and have no water pumping requirements. The submerged gravel/fibrous scrubber rated 3.0 because pressure drop is higher than that of the dry systems. The venturi/fibrous scrubber rated 2.0 because it also requires a liquid pumping system.

\section{Criterion 5d. "Post-accident recovery shall be facilitated by the design of the air cleaning system."}

All systems are external to the containment building and have similar characteristics regarding re-entry to containment, but differ in trapped contaminant disposal. In the scrubber systems most of the contaminants would be suspended in the water and could be processed for permanant storage. The scrubbers were assigned scores of 3.0. The sand bed filter was also rated 3.0 . It was assumed that the contaminants would be left in place. The HEPA filter system was rated 0.0 because removal and disposal of the large number of HEPA units would involve large expediture of cost and manpower.

Criterion 6a. "System costs, capital and maintenance, shall be low."

Maintenance costs are expected to be low for all candidates. However capital costs vary widely and ratings for this criterion were based on capital cost estimates listed in Tables 7 through 11. Results are tabulated be low.

TABLE B-3

SYSTEM RATING BY COST

System

Submerged gravel (HE-2)

Venturi/fibrous (HE-1)

Sand bed $(H E-3)$

HEPA filters (HE-4)
Cost Units

0.7

1.1

16.0

110
Assigned Score

4.0

3.0

1.0

0.0 
Criterion 6b. "Materials and techniques used in construction shall be readily available."

The venturi/fibrous scrubber and the HEPA filter system use standard readily available materials and construction techniques and were assigned scores of 4.0. The sand bed rated 3.5. While construction materials are readily available, only a few 1 arge sand bed filters have been constructed. Therefore, construction techniques may require more $\mathrm{planning}$ than the "optimum" system. The submerged gravel/fibrous scrubber was rated 3.0. No substantial difficulties in construction techniques are expected, but the design lacks a use-history.

Criterion 6c. "Components and equipment shall be readily available." Components and equipment required for all systems, except the sand bed are readily available. The two scrubber systems and the HEPA filter are rated 4.0. The fine sand layer used in the sand bed would probably have to be shipped in from the Midwest; therefore a rating of 2.0 was assigned. 
$\underline{\text { UC-79 }}$ (130)

$\underline{\text { UC }-79 i} \quad$ (23), p

DOE/RRT-HQ

Mail Stop B-107

Washington, DC 20454

Program Division Director

DOE/FFTFPO (5)

Director

HEDL (46)

\begin{tabular}{|c|c|}
\hline $\begin{array}{l}\text { GR Armstrong } \\
\text { JM Atwood } \\
\text { JR Barreca } \\
\text { JJ Broderick } \\
\text { FJ Carvo } \\
\text { JR Collins } \\
\text { WV Cook } \\
\text { EA Evans } \\
\text { JW Hagan } \\
\text { JP Hale } \\
\text { RK Hilliard (2) } \\
\text { AR Hinckley } \\
\text { DW Jeppson } \\
\text { MK Mahaffey } \\
\text { HC Martin } \\
\text { JD McCormack } \\
\text { WM McCormick } \\
\text { GT McDonald } \\
\text { WJ McShane } \\
\text { SE Meyers }\end{array}$ & $\begin{array}{l}W / C-78 \\
W / C-45 \\
W / 221 T(H E) \\
W / B-117 \\
W / 221 T(H E) \\
W / B-117 \\
W / 221 T(H E) \\
W / C-23 \\
W / C-78 \\
W / C-76 \\
W / 221 T \text { (HE) } \\
W / 221 T \text { (HE) } \\
W / 221 T \text { (HE) } \\
W / B-117 \\
W / C-76 \\
W / 221 T \text { (HE) } \\
W / 221 T \text { (HE) } \\
W / 221 T \text { (HE) } \\
W / C-12 \\
W / 221 T \text { (HE) }\end{array}$ \\
\hline
\end{tabular}

\begin{tabular}{ll} 
LD Muhlestein & W/221T(HE) \\
GW Oblisk & W/221T(HE) \\
RK Owen & W/221T(HE) \\
BA Parker & W/22TT(HE) \\
RD Peak & W/C-75 \\
RE Peterson & W/E-18 \\
AK Postma (2) & W/221T(HE) \\
WE Roake & W/C-16 \\
S. Seeman & W/C-79 \\
ER Selle & W/221T(HE) \\
RM Steele & W/221T(HE) \\
DD Stepnewski & W/C-75 \\
AE Waltar & W/C-80 \\
DC Wieners & W/B-106 \\
HH Yoshikawa & W/A-44 \\
MW Young & W/B-106 \\
Central Files (5) & W/C-110 \\
Pub Tervices (2) & W/C-115 \\
Contract Admin & \\
\multicolumn{1}{c}{ SW Berglin } & W/A-21
\end{tabular}

